\title{
REVIEW
}

\section{The integumentary skeleton of tetrapods: origin, evolution, and development}

\author{
Matthew K. Vickaryous ${ }^{1}$ and Jean-Yves Sire ${ }^{2}$ \\ ${ }^{1}$ Department of Biomedical Sciences, Ontario Veterinary College, University of Guelph, Canada \\ ${ }^{2}$ Université Pierre et Marie Curie-Paris 6, UMR 7138-Systématique, Adaptation, Evolution, Paris, France
}

\begin{abstract}
Although often overlooked, the integument of many tetrapods is reinforced by a morphologically and structurally diverse assemblage of skeletal elements. These elements are widely understood to be derivatives of the once all-encompassing dermal skeleton of stem-gnathostomes but most details of their evolution and development remain confused and uncertain. Herein we re-evaluate the tetrapod integumentary skeleton by integrating comparative developmental and tissue structure data. Three types of tetrapod integumentary elements are recognized: (1) osteoderms, common to representatives of most major taxonomic lineages; (2) dermal scales, unique to gymnophionans; and (3) the lamina calcarea, an enigmatic tissue found only in some anurans. As presently understood, all are derivatives of the ancestral cosmoid scale and all originate from scleroblastic neural crest cells. Osteoderms are plesiomorphic for tetrapods but demonstrate considerable lineage-specific variability in size, shape, and tissue structure and composition. While metaplastic ossification often plays a role in osteoderm development, it is not the exclusive mode of skeletogenesis. All osteoderms share a common origin within the dermis (at or adjacent to the stratum superficiale) and are composed primarily (but not exclusively) of osseous tissue. These data support the notion that all osteoderms are derivatives of a neural crest-derived osteogenic cell population (with possible matrix contributions from the overlying epidermis) and share a deep homology associated with the skeletogenic competence of the dermis. Gymnophionan dermal scales are structurally similar to the elasmoid scales of most teleosts and are not comparable with osteoderms. Whereas details of development are lacking, it is hypothesized that dermal scales are derivatives of an odontogenic neural crest cell population and that skeletogenesis is comparable with the formation of elasmoid scales. Little is known about the lamina calcarea. It is proposed that this tissue layer is also odontogenic in origin, but clearly further study is necessary. Although not homologous as organs, all elements of the integumentary skeleton share a basic and essential relationship with the integument, connecting them with the ancestral rhombic scale.
\end{abstract}

Key words dermal scale; evolution; integumentary skeleton; lamina calcarea; osteoderm; tetrapod; turtle carapace.

\section{Introduction}

The early evolutionary history of the dermal skeleton is deeply rooted within the skin. As evidenced by many ancient stem gnathostomes (jawless vertebrates), the dermal skeleton was once the predominant skeletal system, reinforcing the integument with a polymorphic scalation of mineralized tissues (Sire et al. 2009, this volume). Among most modern lineages, particularly teleosts and tetrapods, the integument-bound component of

\section{Correspondence}

Matthew K. Vickaryous, Department of Biomedical Sciences, Ontario

Veterinary College, University of Guelph, Canada.

E: mvickary@uoguelph.ca

Accepted for publication 3 December 2008 the dermal skeleton - the integumentary skeleton - has undergone widespread reduction and/or modification (Moss, 1972; Krejsa, 1979; Zylberberg et al. 1992). What remains is varied in terms of both morphology and structure (Goodrich, 1907; Francillon-Vieillot et al. 1990; Zylberberg et al. 1992; Sire \& Huysseune, 2003). Until recently, however, this phenotypic disparity often obscured the origin and inter-relationships of the individual elements, particularly once they achieved skeletal maturity. Ongoing studies of skeletal tissue structure and development in aquatic non-tetrapods (structural-grade fish) are beginning to provide much needed insight into both the evolution of the integumentary skeleton, and the origin and early structural roles of the integument as a whole (Sire \& Huysseune, 2003; Sire et al. 2009, this volume). For tetrapods far less is known. Although integumentary elements 


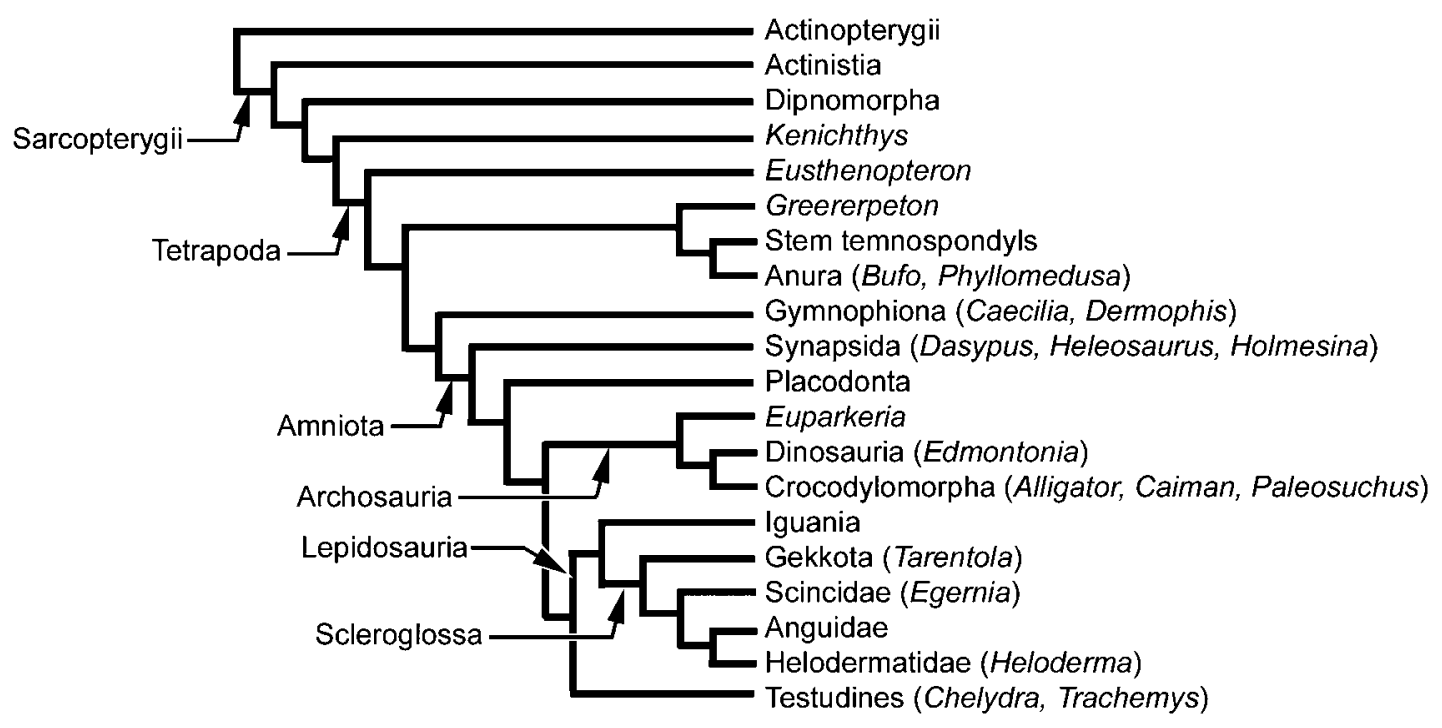

Fig. 1 Simplified phylogeny of Tetrapoda demonstrating the interrelationships of the taxa discussed in the text. The phylogenetic arrangement follows the hypotheses of a diphyletic origin of modern amphibians, turtles as the sister group to lepidosaurs, and iguanians as the sister group to scleroglossans based on the work of Janvier (1996, 2007), Hill (2005), Anderson (2007), Anderson et al. (2008) and Conrad (2008). See text for details.

are frequently employed as taxonomic characters, broadly synthetic evaluations across distantly related taxa are lacking. In particular, the evolution of tetrapod integumentary skeletal organs and their relationship(s) to those elements found in stem gnathostomes and other non-tetrapods remain largely unexplored.

In this review we re-evaluate the origin and evolution of the tetrapod integumentary skeleton by employing comparative developmental and structural data within the context of a revised phylogenetic scheme (Fig. 1). Our initial focus is directed towards summarizing the composition and structural organization of the developing element and surrounding matrix for each major category of integumentary element, including osteoderms, the carapace of turtles and placodonts, gymnophionan dermal scales, and the enigmatic lamina calcarea of anurans (summarized in Table 1). Following this we reconsider the origin and evolution of these elements in the context of a revised phylogenetic hypothesis, building on mounting evidence for a neural crest origin.

The phylogenetic framework for this review (Fig. 1) is based on the work of Janvier (1996, 2007), Hill (2005), Anderson (2007), Anderson et al. (2008) and Conrad (2008), and adopts the recently proposed (or revived) hypotheses of modern amphibians as a paraphyletic assemblage, turtles as the sister group to lepidosaurs, and iguanians as the sister group of scleroglossans.

\section{Early evolution of the vertebrate integumentary skeleton}

An all-encompassing, well-developed integumentary skeleton of overlapping or juxtaposed scale-like elements is common to most stem gnathotomes (Janvier, 1996; Donoghue et al. 2006; Sire et al. 2009, this volume). Although details of gross anatomy are often lacking, each major lineage is characterized by a unique combination of skeletal tissues and matrix organization. Accordingly, palaeohistology of the integumentary skeleton has long been exploited as a reliable source of taxonomic information. For example, the scale-like elements of pteraspidomorphs (Ordovician to Devonian; 480-360 Ma) are characterized by a stratified combination of superficial enameloid overlying tubular dentine (orthodentine), set on a basal plate of acellular bone (aspidin). In contrast, the integumentary elements of anapsids (Silurian to Early Devonian; 443-400 Ma) are exclusively aspidin, whereas those of osteostracans (mid Silurian to Carboniferous; 430-300 Ma) are composed of orthodentine, cellular dentine (mesodentine) and cellular bone. In addition to their obvious diagnostic utility, these data also reveal that the ability of vertebrates to mineralize the integument dates back at least to the Early Ordovician, and that enamel/enameloid, dentine, and bone are all ancient mineralized tissue-types (Donoghue et al. 2006; Sire et al. 2009, this volume).

Among gnathostomes (jawed vertebrates), the structural organization of the integumentary skeleton continues to vary taxonomically: the skull and integumentary elements of placoderms (Silurian to late Devonian, 435-360 Ma) are characterized by cellular bone covered by a cellular dentine with polarized cell processes (semidentine), whereas the scalation of chondrichthyans [= odontodes (placoid scales)] consists of a superficial layer of enameloid, capping an orthodentine crown, attached to the dermis by bone of attachment (Goodrich, 1907; Miyake et al. 1999; 


\begin{tabular}{|c|c|c|c|c|c|c|}
\hline Taxon & $\begin{array}{l}\text { Skeletal } \\
\text { element }\end{array}$ & $\begin{array}{l}\text { Distribution and adult } \\
\text { morphology }\end{array}$ & Skeletally mature tissue type & Organization & Skeletogenesis & References \\
\hline $\begin{array}{l}\text { Stem } \\
\text { tetrapods }\end{array}$ & osteoderm & $\begin{array}{l}\text { dorsal and ventral body surfaces; } \\
\text { multiple rhombic scale-like } \\
\text { elements }\end{array}$ & $\begin{array}{l}\text { cellular bone (lamellar and Sharpey- } \\
\text { fibred bone) }\end{array}$ & $\begin{array}{l}\text { cortex of compact bone } \\
\text { surrounding an inner } \\
\text { cancellous core }\end{array}$ & uncertain & $\begin{array}{l}\text { Ørvig, 1957; Jarvik, 1980; } \\
\text { Dias \& Richter, } 2002\end{array}$ \\
\hline \multirow[t]{2}{*}{ Anura } & osteoderm & $\begin{array}{l}\text { mostly dorsal body surface; } \\
\text { usually multiple small polygonal } \\
\text { elements creating a juxtaposed } \\
\text { mosaic but sometimes larger } \\
\text { plates fused to neural spines }\end{array}$ & $\begin{array}{l}\text { cellular bone (parallel-fibred and/or } \\
\text { lamellar bone) }\end{array}$ & non-stratified compact bone & $\begin{array}{l}\text { uncertain: hypothesized } \\
\text { to include bone } \\
\text { metaplasia }\end{array}$ & Ruibal \& Shoemaker, 1984 \\
\hline & $\begin{array}{l}\text { lamina } \\
\text { calcarea }\end{array}$ & $\begin{array}{l}\text { distributed across body as a thin } \\
\text { intradermal layer; sometimes } \\
\text { segmented to form granular } \\
\text { bodies known as dermolita }\end{array}$ & $\begin{array}{l}\text { acellular, non-collagenous matrix } \\
\text { that contains proteoglycans } \\
\text { (including glycosaminoglycans) and } \\
\text { hydroxyapatite-like crystals }\end{array}$ & homogeneous tissue & $\begin{array}{l}\text { uncertain: hypothesized } \\
\text { to be deposited by } \\
\text { fibroblasts }\end{array}$ & $\begin{array}{l}\text { Muzzi, 1968; Elkan, 1976; } \\
\text { Sampson et al. 1987; } \\
\text { Toledo \& Jared, 1993; } \\
\text { Katchburian et al. 2001; } \\
\text { Schwinger et al. } 2001\end{array}$ \\
\hline Gymnophiona & $\begin{array}{l}\text { dermal } \\
\text { scale }\end{array}$ & $\begin{array}{l}\text { flat, disc-like elements embedded } \\
\text { in pouches associated with body } \\
\text { rings }\end{array}$ & $\begin{array}{l}\text { hypermineralized upper tissue } \\
\text { comparable with the limiting layer of } \\
\text { teleost elasmoid scales; elasmodine }\end{array}$ & $\begin{array}{l}\text { plywood-like arranged basal } \\
\text { plate of elasmodine capped by } \\
\text { superficial hypermineralized } \\
\text { granules (squamulae) }\end{array}$ & $\begin{array}{l}\text { uncertain: hypothesized } \\
\text { to develop similar to } \\
\text { elasmoid scales }\end{array}$ & $\begin{array}{l}\text { Zylberberg et al. 1980; } \\
\text { Zylberberg \& Wake, } 1990\end{array}$ \\
\hline Synapsida & osteoderm & $\begin{array}{l}\text { dorsal body surface: polygonal } \\
\text { and rectangular elements often } \\
\text { organized into articulating } \\
\text { mosaics (= shields and carapaces) }\end{array}$ & $\begin{array}{l}\text { cellular bone (parallel-fibred, } \\
\text { lamellar, Sharpey-fibred bone) with } \\
\text { limited amounts of unmineralized } \\
\text { fibrous connective tissue }\end{array}$ & $\begin{array}{l}\text { cortex of compact bone } \\
\text { surrounding an inner } \\
\text { cancellous core }\end{array}$ & $\begin{array}{l}\text { intramembranous } \\
\text { ossification }\end{array}$ & $\begin{array}{l}\text { Hill, 2006; Vickaryous \& } \\
\text { Hall, } 2006\end{array}$ \\
\hline Archosauria & osteoderm & $\begin{array}{l}\text { mostly dorsal body surface but } \\
\text { may develop within virtually any } \\
\text { portion of the dermis (e.g. eyelids, } \\
\text { cheeks); often disc or plate-like in } \\
\text { shape }\end{array}$ & $\begin{array}{l}\text { cellular bone (woven-fibred, parallel- } \\
\text { fibred, lamellar); calcified and } \\
\text { unmineralized fibrous connective } \\
\text { tissue }\end{array}$ & $\begin{array}{l}\text { cortex of compact bone } \\
\text { surrounding an inner } \\
\text { cancellous core }\end{array}$ & $\begin{array}{l}\text { fibrous connective tissue } \\
\text { mineralization, bone } \\
\text { metaplasia }\end{array}$ & $\begin{array}{l}\text { Schmidt, 1914; Moss, 1969; } \\
\text { Scheyer \& Sander, 2004; } \\
\text { Main et al. 2005; } \\
\text { Vickaryous \& Hall, } 2008\end{array}$ \\
\hline Lepidosauria & osteoderm & $\begin{array}{l}\text { variable distribution: often } \\
\text { restricted to head and/or dorsal } \\
\text { body surface but may encase the } \\
\text { entire body; highly polymorphic: } \\
\text { granular, bead-like, vermiform, } \\
\text { compound and imbricating scale- } \\
\text { like shapes }\end{array}$ & $\begin{array}{l}\text { cellular bone (woven-fibred, parallel- } \\
\text { fibred, lamellar); calcified and } \\
\text { unmineralized fibrous connective } \\
\text { tissue; and (in some taxa) an } \\
\text { enigmatic collagen-poor capping } \\
\text { tissue }\end{array}$ & $\begin{array}{l}\text { often stratified into two } \\
\text { distinct layers of which the } \\
\text { basal portion is always bone } \\
\text { (parallel-fibred or lamellar); } \\
\text { superficial layer is variable and } \\
\text { may consist of woven-fibred } \\
\text { bone or an enigmatic collagen- } \\
\text { poor tissue }\end{array}$ & $\begin{array}{l}\text { uncertain: evidence } \\
\text { suggests both bone } \\
\text { metaplasia and } \\
\text { intramembranous } \\
\text { ossification }\end{array}$ & $\begin{array}{l}\text { Moss, 1969; Zylberberg \& } \\
\text { Castanet, 1985; Levrat- } \\
\text { Calviac et al. 1986; Levrat- } \\
\text { Calviac \& Zylberberg, } 1986\end{array}$ \\
\hline Testudines & carapace & $\begin{array}{l}\text { skeletal complex consisting of } \\
\text { multiple tightly articulating and } \\
\text { fused bony elements enclosing } \\
\text { the dorsal body surface (trunk), } \\
\text { including the pectoral apparatus }\end{array}$ & $\begin{array}{l}\text { cellular bone (lamellar); plywood-like } \\
\text { arrangement of collagen fibres in the } \\
\text { external cortex of some trionychids }\end{array}$ & $\begin{array}{l}\text { trilaminar organization: } \\
\text { compact external and internal } \\
\text { cortices and a cancellous } \\
\text { central core }\end{array}$ & $\begin{array}{l}\text { perichondral ossification } \\
\text { (ribs and vertebrae); } \\
\text { intramembranous } \\
\text { ossification (nuchal } \\
\text { element and bony } \\
\text { spicules between ribs) }\end{array}$ & $\begin{array}{l}\text { Gilbert et al. 2001, 2007; } \\
\text { Cebra-Thomas et al. 2007; } \\
\text { Scheyer \& Sanchez- } \\
\text { Villagra, 2007; Scheyer \& } \\
\text { Sander, 2007; Scheyer } \\
\text { et al. } 2007\end{array}$ \\
\hline
\end{tabular}


Sire \& Huysseune, 2003). For osteichthyans, sister group to chondrichthyans, the plesiomorphic integumentary skeleton consists of large numbers of robust overlapping rhombic scales organized into obliquely oriented rows. These rhombic scales have two structural forms corresponding to the ray-finned-lobe-finned dichotomy. Basal actinopterygians have ganoid scales, whereas basal sarcopterygians have cosmoid scales.

Ganoid scales are identified by the presence of ganoine, a shiny, acellular hypermineralized tissue structurally identical to enamel, typically overlying layers of orthodentine and basal plate of lamellar bone (Goodrich, 1907; Sire et al. 1987). Unlike enamel, ganoine is multilayered and, as evidenced by modern taxa, always localized deep to an epithelium (Goodrich, 1907; Sire, 1990; Francillon-Vieillot et al. 1990; Huysseune, 2000). Based on the study of scale development, ganoid scales are hypothesized to have given rise to elasmoid scales (Sire, 1990; Sire \& Huysseune, 2003; Sire et al. 2009, this volume).

The second major structural form of rhombic scale is the cosmoid scale of basal sarcopterygians. At first glance, cosmoid scale histology compares well with that of the ganoid scale: a shiny superficial tissue comparable with enamel or enameloid, overlying a stacked sequence of dentine and lamellar bone (Goodrich, 1907; Meinke, 1984). However, cosmoid scales (and the tissue complex known as cosmine) are uniquely characterized by an intrinsic, interconnected canal system, with numerous flask-shaped cavities and superficial pores. The oldest known examples of cosmine come from various Devonian sarcopterygians, dated around $\sim 15$ to $410 \mathrm{Ma}$, including Psarolepis romeri, Achoania jarvikii, Styloichthys changae and Meemannia eos (Yu, 1998; Zhu et al. 1999, 2001, 2006; Zhu \& Yu, 2002). Cosmoid scales were present among basal-most members of both Actinistia (coelacanths; Cloutier, 1991; Janvier, 1996) and Dipnomorpha (lungfish; Meinke, 1984; Janvier, 1996), but were independently lost in each lineage. The cosmoid scale (and cosmine tissue) is extinct, and is no longer found in living species.

\section{Structure and development of the tetrapodomorph integumentary skeleton}

The transition from lobe-finned aquatic sarcopterygians to limb and digit-bearing stem tetrapods (tetrapodomorphs; Ahlberg, 1991) took place during the late Devonian. Coinciding with the acquisition of features permitting an increasingly terrestrial existence, the integumentary skeleton of tetrapodomorphs underwent a number of important changes. As in other basal sarcopterygians, the integument of the oldest and most basal forms was jacketed by numerous thick cosmoid scales (e.g. Kenichthys campbelli, Gogonasus andrewsae and Osteolepis spp.; Ørvig, 1957; Jarvik, 1980; Zhu \& Ahlberg, 2004; Long et al. 2006). Among more deeply nested (and recently derived) tetrapodan taxa (e.g. Eusthenopteron foordi, Panderichthys rhombolepis, Tiktaalik rosea and Ichthyostega stensioei), the odontogenic-derived tissues (dentine, enameloid, and ganoine) and pore-canal systems were lost, resulting in an integumentary skeletal elements composed primarily of bone (Ørvig, 1957; Jarvik, 1980; Daeschler et al. 2006; see 'A revised scenario for the evolution and diversification of the integumentary skeleton in tetrapods' below).

\section{Osteoderms and carapaces}

\section{Osteoderms}

Unquestionably, osteoderms represent the most commonly identified and documented element of the tetrapod integumentary skeleton. As classically defined, an osteoderm is a structural category of mineralized organ entrenched within the dermis (Gadow, 1901; Camp, 1923; Romer, 1956; Francillon-Vieillot et al. 1990; Vickaryous \& Hall, 2008). Although generally plate-like, these elements vary greatly in size, shape, surface ornamentation, articulation and geometry both between and within taxa (Grant, 1944; Hoffstetter, 1962). Whereas some of this variation coincides with differences in the thickness and structure of the integument, particularly the dermis, much of the disparity remains structurally and functionally enigmatic.

Aptly named, the skeletal matrix of osteoderms always includes osseous tissue. However, osteoderms are not histologically uniform. Most osteoderms include variable amounts of mineralized and unmineralized fibrous connective tissue, and bone marrow. In some taxa the superficial surface is capped by an unnamed collagenpoor/cell-poor highly mineralized tissue of uncertain affinity (Moss, 1969; Zylberberg \& Castanet, 1985; Zylberberg et al. 1992; Vickaryous \& Hall, 2006, 2008). Furthermore, the structural arrangement of the osseous matrix is variable, and may combine osteoid (premineralized bone matrix), woven-fibred, parallel-fibred (fibrolamellar), lamellar, and/ or Sharpey-fibred bone. Given this heterogeneous composition, Moss $(1969,1972)$ proposed that the term 'osteoderm' should be replaced with 'sclerification'.

Osteoderms are common to representative members of most major tetrapod lineages, including 'amphibians' (herein considered to be paraphyletic), lepidosaurs (exclusive of ophidians), archosaurs (exclusive of avians and pterosaurs), turtles, parareptiles (pareiasaurs and procolophonids), placodonts (sauropterygians), and even some synapsids (mostly xenarthrans) (e.g. Moss, 1969; Barrett et al. 2002; Castanet et al. 2003; Hill, 2005; Cisneros, 2008; Vickaryous \& Hall, 2008). As will be discussed, the bony scales of the earliest tetrapods are also structurally consistent with osteoderms, pushing back the origin of these integumentary elements to the late Devonian. However, although osteoderms are taxonomically widespread, their specific phylogenetic distribution is highly irregular. For 
example, osteoderms have been reported for many scleroglossan lepidosaurs (e.g. anguids, scincids, helodermatids), but only for a single species (out of $\sim 1000$; see Conrad \& Norell, 2007) of iguanian (Amblyrhynchus cristatus, the marine iguana; de Queiroz, 1987). Similarly, osteoderms have been well-documented in many herbivorous dinosaur groups (e.g. ankylosaurs, stegosaurs, and some sauropods) but only in one carnivorous dinosaur, Ceratosaurus nasicornis (Martill et al. 2000). As such, it is often suggested that osteoderms have been repeatedly lost and/or independently gained. One recent study of amniotes proposed that postcranial osteoderms may have arisen independently at least five times (Hill, 2005). More recently, it has been argued that osteoderms are an example of what has been termed deep homology: a latent but plesiomorphic ability (genetic, cellular, developmental, and structural) to form structures and organs (Main et al. 2005; Hill, 2006; Vickaryous \& Hall, 2008). And whereas a generalized protective function seems almost undeniable, with rare exceptions (e.g. Alexander et al. 1999) specific details on the biomechanics of osteoderms as part of an integrated system have yet to be determined. Furthermore, alternative/additional functional roles cannot be ruled out (e.g. Seidel, 1979; Frey, 1988; Scheyer \& Sander, 2004; Hill, 2005; Main et al. 2005; Dilkes \& Brown, 2007). Adding to the uncertainty, the term osteoderm (in use for more than a century; Gadow, 1901; Camp, 1923; Romer, 1956 ) is routinely substituted with one or more ambiguous synonyms including armour, dermal ossification, dermal plate, osteoscute and scute (e.g. Camp, 1923; Sibtain, 1938; DeMar, 1966; de Ricqlès et al. 2001; Main et al. 2005; Dilkes \& Brown, 2007).

For the vast majority of tetrapods, osteoderms are strictly documented as adult life stage taxonomic characters, and remarkably little is known about their structure and development, particularly at the molecular level. As a consequence, many broad generalizations have been extracted from relatively few, distantly related taxa. It is therefore necessary and appropriate to approach this review in a systematic fashion.

Basal tetrapods and stem temnospondyls. Among basal non-digit-bearing tetrapods the integumentary skeleton consists of large numbers of thick, imbricated scales. However, unlike their immediate ancestors, the integumentary elements of taxa such as Eusthenopteron foordi are composed of fibrolamellar bone without any odontogenic tissues (Ørvig, 1957; Jarvik, 1980). Significantly, this tissue motif is consistent with the structural composition of osteoderms. In section, these scale-shaped osteoderms demonstrate an outer cortex of compact bone and an inner cancellous core.

A well-developed integumentary skeleton is also retained by many early digit-bearing forms such as temnospondyl amphibians and their closest relatives. For some (e.g.
Greererpeton burkemorani; Fig. 2) these elements are highly variable and may include a combination of thin and overlapping scales (ovoid to spindle-shaped), granular pellets, and/or robust plates. Based on gross morphology it has been suggested that the pellets and plates are osteoderms, whereas the overlapping scales are comparable with the dermal scales of gymnophionans (e.g. Witzmann, 2007; see this section and 'Origin and evolution'). It should be noted, however, that such a morphology falls well within the phenotypic range of osteoderms, even among modern taxa such as lepidosaurs (see below). Reportedly, scale-like integumentary elements of the temnospondyl Trimerorhachis insignis are composed of acellular bone (Olson, 1979). As there is no histological evidence to support a comparison with gymnophionan-like dermal scales, we suggest that the identification of all temnospondyl integumentary elements as osteoderms is more consistent with the available data.

A large growth series of the temnospondyl Sclerocephalus sp. reveals that osteoderms were already present during larval stages. As individuals mature, elements along the ventral body surface changed their morphology from ovoid to spindle-shaped (Schoch, 2003; Witzmann, 2007). In Australerpeton cosgriffi, ontogenetic changes in gross morphology were accompanied by modifications of tissue structure (Dias \& Richter, 2002). In subadults, osteoderms primarily consist of Sharpey-fibred bone and cellrich compact lamellar bone with relatively few vascular canals. In larger and more skeletally mature specimens, osteoderms have a cancellous core surrounded by compact bone containing Sharpey's fibres. The bony matrix also demonstrates evidence of resorption, remodeling, and secondary osteons (Dias \& Richter, 2002). A similar pattern of histological organization has been reported for various other basal tetrapods and early amphibians (Castanet et al. 2003).

Anura. Osteoderm-bearing anurans include a variety of distantly related taxa including representative ceratophryines (Hylactophryne augusti and some but not all species of Ceratophrys and Lepidobatrachus), phyllomedusines (Phyllomedusa bicolor, Phyllomedusa vaillanti), a hemiphractine (Gastrotheca weinlandii), a pelobatid (Megophrys nasuta), the brachycephalid Brachycephalus ephippium, and reportedly some dendrobatids (Cope, 1868; Gadow, 1901; Trueb, 1973; Lynch, 1982; Ruibal \& Shoemaker, 1984; Fabrezi, 2006). In most cases they are restricted to the dorsal skin of the head and trunk, although for some taxa (e.g. Phyllomedusa spp., H. augusti) the distribution may include parts of the ventral body surface and limbs. In addition, osteoderms have been tentatively identified in the albanerpetontid Celtes ibericus, an extinct species of salamander-like 'amphibian' (McGowan \& Evans, 1995).

There are two main forms of anuran osteoderm. In most taxa, individual elements are small $\left(<3 \mathrm{~mm}^{2}\right)$, confined 

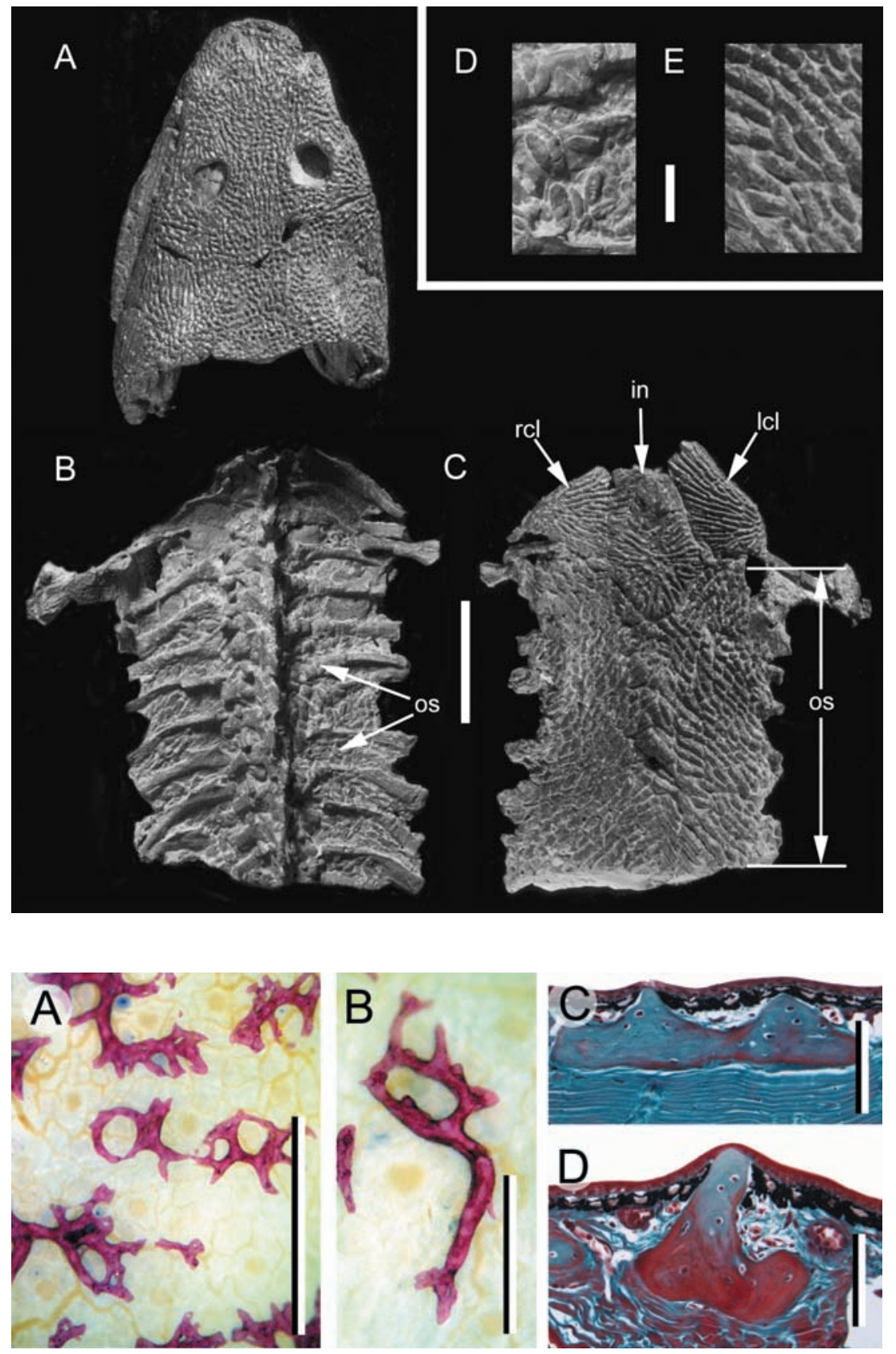

Fig. 2 Basal tetrapod osteoderms. Greererpeton burkemorani (Stem temnospondyl, Early Carboniferous: Cleveland Museum of Natural History 11090) in (A,B,D) dorsal and $(C, E)$ ventral views. Osteoderms are absent from across the skull (A), modestly developed across the dorsal body surface (B), but are abundant and highly organized along the ventral body surface $(C)$, beginning immediately caudal to the pectoral apparatus. Note the prominent ornamentation embossing the skull (A), and the interclavicle and clavicles (C), coinciding with a lack of osteoderms across these regions. Close-up views of osteoderms from the dorsal (D) and ventral body surfaces (E). in (interclavicle), Icl (left clavicle), os (osteoderms), rcl (right clavicle). Scale bars: $A-C=50 \mathrm{~mm}, \mathrm{D}-\mathrm{E}=3 \mathrm{~mm}$. Photographs courtesy of L. Russell and Dr. M. Ryan, Cleveland Museum of Natural History, Cleveland, OH, USA.

Fig. 3 Anuran osteoderms. Phyllomedusa bicolor (Phyllomedusinae, Extant). (A,B) Adult osteoderms from the dorsal body surface, prepared as whole-mounts using Alizarin red (single-stained). (C,D) Transverse sections (dorsal towards the top) of dorsal body surface osteoderms, Masson's trichrome staining. Osteoderms reside entirely within the stratum superficiale. Note the development of large spines displacing the epidermis dorsally. Scale bars: $A, B=0.25 \mathrm{~mm} ; C, D=100 \mu \mathrm{m}$. Specimens courtesy of Dr. J. Bogart and M.-T. Rush, University of Guelph, Guelph, Canada. largely to the stratum superficiale, and distributed across a broad area of integument (Fig. 3). However, in ceratophryines and $B$. ephippium each osteoderm is larger in size $\left(>3 \mathrm{~mm}^{2}\right)$, occupies the full thickness of the dermis (both the strata superficiale and compactum), and is restricted to positions dorsal to the vertebral column (Trueb, 1973; Lynch, 1982; Fabrezi, 2006). Similar shield-like osteoderms situated above the vertebral column have also been reported for various stem temnospondyls (Dilkes \& Brown, 2007).

Structurally, most anuran osteoderms are composed of well-vascularized parallel-fibred and/or lamellar bone. Apparently unique to $M$. nasuta and $H$. augusti, the matrix includes a large amount of orthogonally arranged collagen lamellae, with relatively few osteocyte lacunae and vascular canals (Ruibal \& Shoemaker, 1984). How this organization differs from lamellar bone remains uncertain.

The development of anuran osteoderms has yet to be documented, although the onset of skeletogenesis appears to be relatively delayed, as evidenced by the absence of osteoderms in newly metamorphosed $P$. vaillanti, Lepidobatrachus laevis, and juvenile Ceratophrys ornata (Ruibal \& Shoemaker, 1984). Based on structural comparisons with adult lepidosaur osteoderms, including the presence of numerous Sharpey's fibres, it is assumed that the formation and growth of anuran osteoderms involve metaplastic ossification (Ruibal \& Shoemaker, 1984). 
Archosauria. Osteoderms are common among many fossil and modern archosaurs, including parasuchians (phytosaurs), aetosaurs, 'rauisuchians', crocodylomorphs (including extant Crocodylia), several lineages of dinosaurs, various aquatic taxa of uncertain affinity (e.g. Sikannisuchus huskyi, Qianosuchus mixtus: Nicholls et al. 1998; Li et al. 2006) and the basal form Euparkeria capensis (Romer, 1956; Ewer, 1965; Hill, 2005). In most taxa, individual elements are organized into multiple transverse or parasagittal rows across the dorsolateral surfaces of the body, beginning caudal to the skull and continuing past the base of the tail (Fig. 4A; Huxley, 1860; Ross \& Mayer, 1983; Martz \& Small, 2006). For some taxa, the distribution is considerably more enveloping and may include the ventral body wall, cheeks (Fig. 4B,C), eyelids (Fig. 4D), and the distal end of the tail, thus creating a tail club
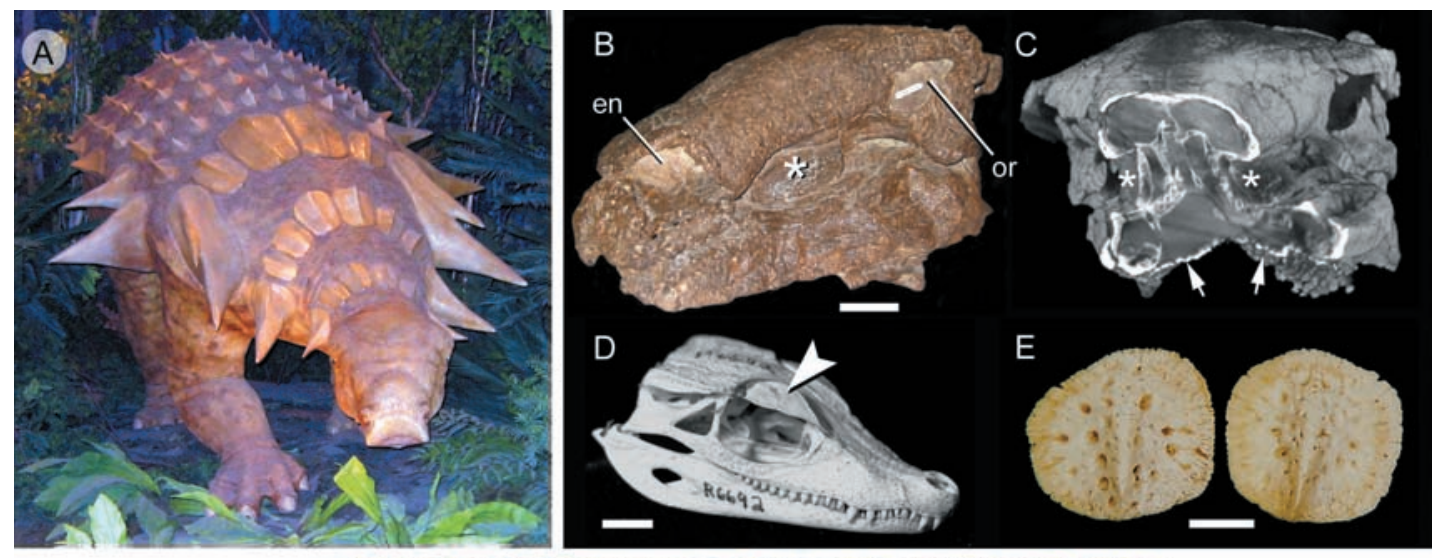

F

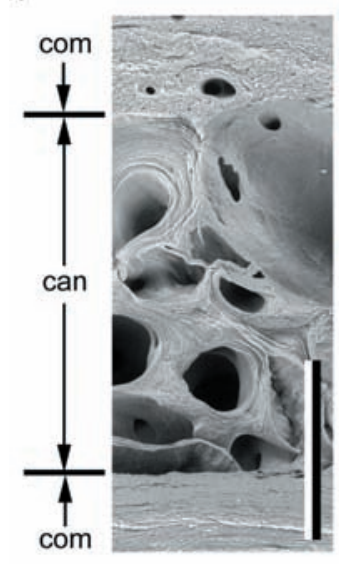

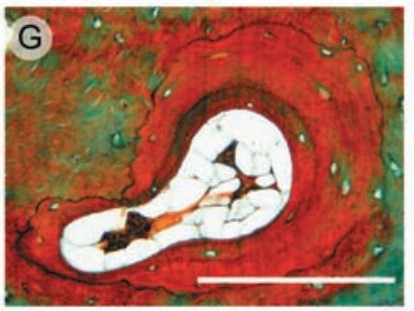

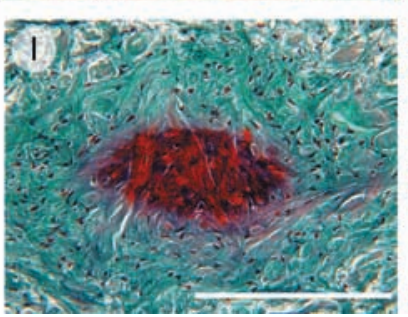

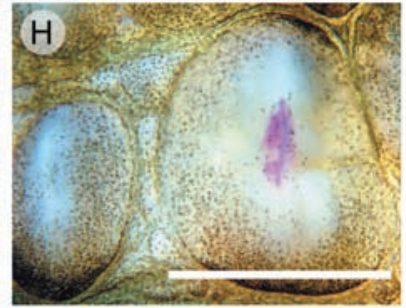

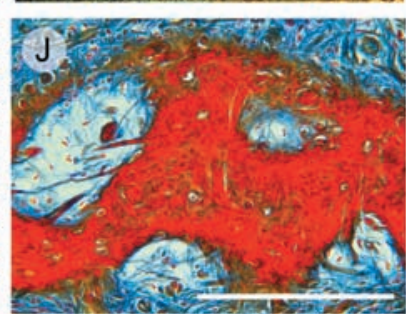

K

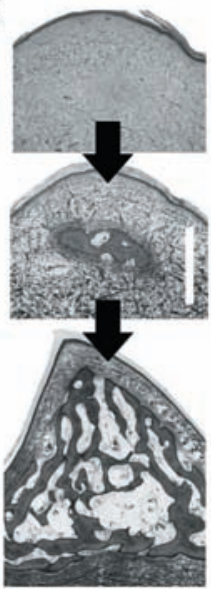

Fig. 4 Archosaur osteoderms. (A-C) Edmontonia rugosidens (Ankylosauria, Late Cretaceous). (A) Reconstruction on display at the Royal Tyrrell Museum of Palaeontology, Drumheller, Alberta, demonstrating various plate-like and spine-shaped osteoderms. (B) Skull (American Museum of Natural History, New York, 5381) in right rostrodorsal view. (C) Computed tomography reconstruction of the skull in (B) with the rostrum truncated to indicate the in situ position of the cheek region osteoderms, and a series of small, granular osteoderms across the throat (small arrows). The asterisks (*) in both (A) and (B) identify the presence of an osteoderm embedded in the cheek region, lateral to the tooth rows. (D) Paleosuchus palpebrosus skull (Crocodylia, Extant: Royal Ontario Museum, Toronto, Paleobiology collection R6692) demonstrating a well-developed osteoderm (= palpebral) within the eyelid (large arrowhead). (E) Alligator mississippiensis (Crocodylia, Extant). Cervical osteoderms demonstrating a common pattern of ornamentation among archosaurs: superficial pitting. (F) Caiman c. crocodilus (Crocodylia, Extant: Royal Ontario Museum, Toronto, Paleobiology collection R7719). Transverse section through a cervical osteoderm. The structural organization includes an outer and an inner cortex of compact bone (com) surrounding a cancellous core (can). (G,I-K) Longitudinal sections (dorsal towards the top). (G) A. mississippiensis adult, cervical osteoderm, Masson's trichrome staining. Note the resorption of woven-fibred bone and newly deposited lamellar bone matrix. $(\mathrm{H})$ A. mississippiensis subadult, cervical osteoderms prepared as whole-mounts using Alizarin red (single-stained). The initial site of mineralization (red staining) is within the keel of the largest presumptive element. (I) Same specimen as (H), sectioned and stained with a modified Masson's trichrome (Cole \& Hall, 2004). Mineralization (red staining) is initiated without the formation of a cell condensation. This mode of ossification is consistent with bone metaplasia. (J) A. mississippiensis subadult [slightly older than (I)], cervical osteoderm, Mallory's trichrome. Numerous extrinsic collagen fibres are becoming incorporated into the osteoderm matrix. Note the absence of a clear osteoblastic front. (K) Sequence of osteoderm development beginning as a weakly defined primordium of dense irregular connective tissue (top panel), followed by mineralization within the centre of the keel (middle panel), and finally expansion of the osteoderm into the majority of the keel and the deposition of bone (bottom panel). Scale bars: $B-C=50 \mathrm{~mm}, \mathrm{D}=100 \mathrm{~mm}, \mathrm{E}=30 \mathrm{~mm}, \mathrm{~F}, \mathrm{~K}=1 \mathrm{~mm}$, $\mathrm{G}, \mathrm{I}, \mathrm{J}=40 \mu \mathrm{M}, \mathrm{H}=5 \mathrm{~mm}$. en (external naris), or (orbit). Micrograph (F) courtesy of M. Burns, University of Alberta, Edmonton, Canada. 
(Huxley, 1860; Coombs, 1972, 1995; Dong et al. 1989; Vickaryous \& Russell, 2003; Vickaryous, 2006; Vickaryous \& Hall, 2008).

Coinciding with the taxonomic diversity of archosaurs, osteoderms demonstrate a considerable range of morphologies, ranging from small granular mineralizations (3-10 $\mathrm{mm})$ and coin-shaped discs $(10-100 \mathrm{~mm})$, to massive plates and elongate spine-like elements ( $>200 \mathrm{~mm}$ in maximum dimensions) (e.g. Martill et al. 2000; de Ricqlès et al. 2001; Vickaryous et al. 2004; Main et al. 2005; Vickaryous \& Hall, 2008). Based on dimensions of the largest dinosaur osteoderms ( $250 \mathrm{~mm}$ diameter and $70 \mathrm{~mm}$ in thickness: attributed to a titanosaurid sauropodomorph), Dodson et al. (1998) estimated the dermis to be more than twice as thick as that of modern elephants (some 10-32 mm; Haynes, 1991). For many taxa the superficial-most surfaces are enhanced by some form of ornamentation, including keels and/or points of varying proportions, and numerous shallow pits and fovea. At least among crown members, each osteoderm has a $1: 1$ relationship with an overlying epidermal scale.

As in early tetrapods, in archosaurs skeletally mature osteoderms are characterized by an outer cortex of compact bone (fibrolamellar and/or lamellar) invested with numerous Sharpey's fibres (Enlow \& Brown, 1957; Moss, 1969; Martill et al. 2000; de Ricqlès et al. 2001; Barrett et al. 2002; Scheyer \& Sander, 2004; Main et al. 2005; Hill \& Lucas, 2006). In some taxa (e.g. crocodylians, some ankylosaurs), the compact layer also demonstrates evidence of periodic growth (= annuli; Hutton, 1986; Tucker, 1997; de Ricqlès et al. 2001; Main et al. 2005; Hill \& Lucas, 2006; see below). Deep to the cortex is a central core of cancellous bone demonstrating evidence of localized resorption and secondary osteon formation (Fig. 4F,G). Throughout the bony matrix there may be remnant seams of woven-fibred bone, and calcified and uncalcified fibrous connective tissue. In describing the fibrous organization of ankylosaurian dinosaur osteoderms from the Antarctic, de Ricqlès et al. (2001; see also Scheyer \& Sander, 2004) reported that three orthogonal systems were evident, similar to the arrangement of collagen fibres previously described for the stratum compactum (Sire et al. 2009, this volume). Various taxa may also develop osteoderms with hypertrophic keels (e.g. stegosaurs, the crocodylian Akantosuchus langstoni). Uniquely, the tissue matrix of the keel is penetrated by a prominent system of large diameter intrinsic neurovascular channels also known as 'pipes' (de Buffrénil et al. 1986; Main et al. 2005; Hill \& Lucas, 2006).

At least among modern crocodylians, osteoderms are localized within the stratum superficiale, although the deepest margins may be in contact with (or partially embedded within) the stratum compactum (Schmidt, 1914; Martill et al. 2000; Salisbury \& Frey, 2000; Vickaryous \& Hall, 2008). The onset of development is delayed compared with the rest of the skeleton, and therefore osteoderms are frequently absent from relatively small (= young) individuals (Maryañska, 1977; Jacobs et al. 1994; Vickaryous et al. 2001; Vickaryous \& Hall, 2008; Sire, pers. obs.). Skeletal formation is asynchronous, beginning dorsal to the neck and pectoral apparatus before spreading across the remainder of the body (Vickaryous \& Hall, 2008).

Details of osteoderm skeletogenesis are derived primarily from the study of modern crocodylians (Schmidt, 1914; Vickaryous \& Hall, 2008). In advance of calcification, each osteoderm is prefaced by a dense knot-like aggregation of fibrous connective tissue localized within the keel of the epidermal scale (Fig. $4 \mathrm{H}, \mathrm{I}$ ). Except for its thickened appearance, this osteoderm primordium does not differ histologically or histochemically from the surrounding matrix of the stratum superficiale. Although cells are present (mostly fibroblast-like), there is no evidence of a cell condensation or the deposition of osteoid. Mineralization begins within the centre of the primordium, incorporating many of the pre-existing collagen fibres, but no bone is present at this stage. With continued skeletogenesis, the osteoderm primordium extends into adjacent areas with the development of calcified spicules. Gradually patches of woven-fibred bone appear, merging into the mineralized fibrous tissue, followed by the deposition of parallel-fibred and lamellar bone (Fig. 4K).

Growth marks indicating periodic bone deposition are present in the outer cortex of modern crocodylian osteoderms, and have been successfully employed to estimate individual age (e.g. Hutton, 1986; Tucker, 1997). It is important to note, however, that this technique has two distinct limitations: (1) breeding females exhibit greater amounts of remodeling than males or non-breeding females (Hutton, 1986); and (2) the reliability of such estimations is known to decrease among individuals greater than 20 years in age (Tucker, 1997). Therefore the accuracy of this method is heavily dependent on sex, breeding status, and age, and hence is problematic for the study of extinct taxa.

Lepidosauria. Among lepidosaurs, osteoderms are absent from all snakes and amphisbaenians, and all but a single species of sphenodontid (the fossil form Pamizinsaurus tlayuaensis; Reynoso, 1997) but are well-represented in scleroglossan 'lizards', including anguids, cordyliforms, helodermatids, scincids, shinisaurids, xantusiids, xenosaurids, some lacertids and varanids, and a few gekkonids (Gadow, 1901; Camp, 1923; McDowell \& Bogert, 1954; Read, 1986; Estes et al. 1988; Gao \& Norell, 2000; Maisano et al. 2002; Barrett et al. 2002; Krause et al. 2003; see also Bever et al. 2005). Although they are most commonly localized on the dorsal surface of the body and head (Gadow, 1901; Camp, 1923; Read, 1986; Estes et al. 1988), in some taxa the distribution is almost ubiquitous across the body (e.g. gerrhosaurids, various anguids, scincids, and some species of the gekkonid Tarentola). As for other 

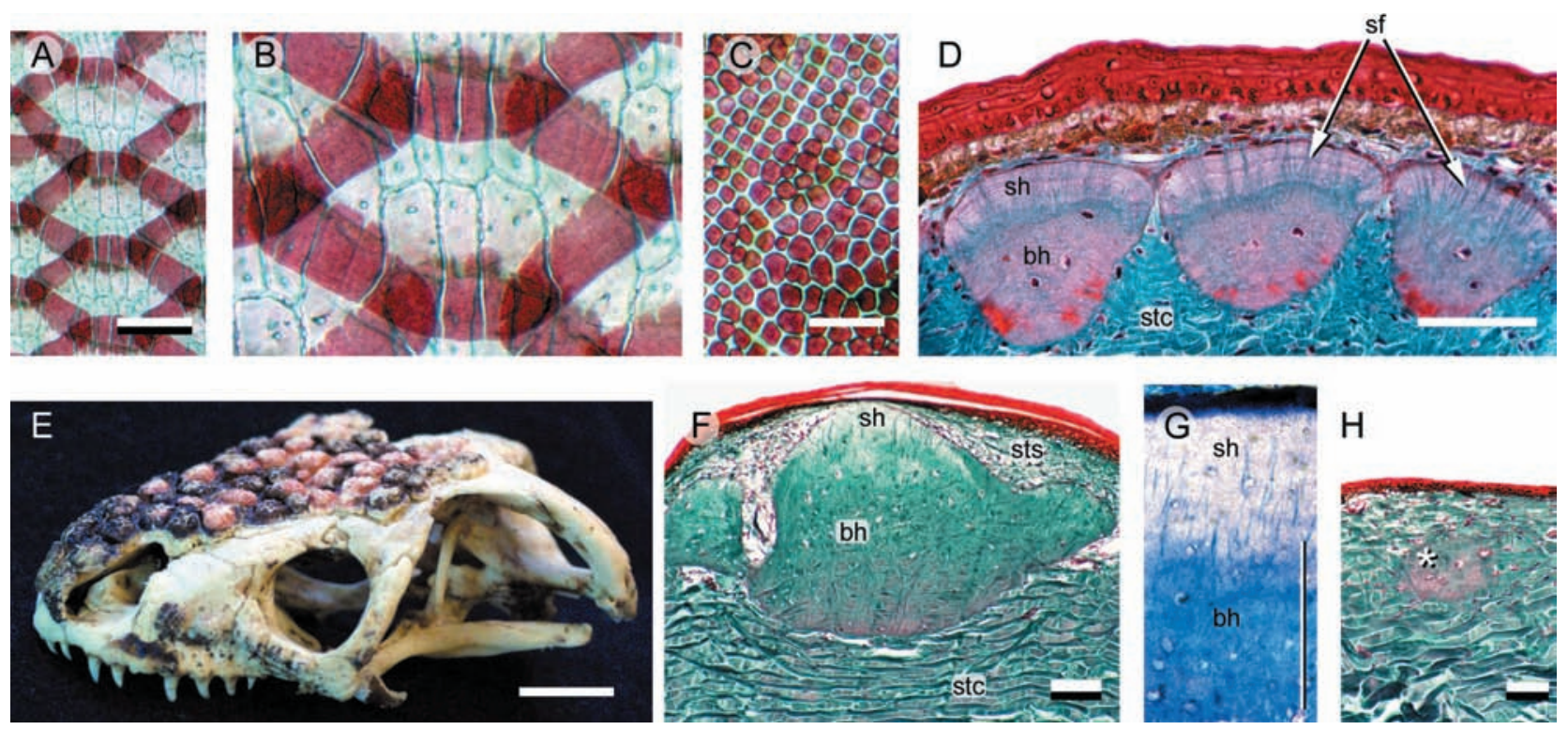

Fig. 5 Lepidosaur osteoderms. (A-C) Alizarin red single-staining. (D,F-H) Longitudinal sections (dorsal towards the top). (A,B) Egernia sp. (Scincidae, Extant). Among scincids, most postcranial osteoderms overlap one another and demonstrate a compound or fractured morphology. (C) Tarentola mauritanica (Gekkota, Extant) postcranial osteoderms with a granular morphology. (D) Postcranial osteoderms from T. annularis (Gekkota, Extant) stained with Masson's trichrome. Each osteoderm has two distinct tissue regions. The superficial region resides entirely within the stratum superficiale, and is collagen-poor with virtually no incorporated cells. The basal region resides within the stratum compactum, and consists of compact (cellular) bone. Sharpey's fibres anchor both regions within the surrounding dermis. (E-H) Heloderma horridum (Helodermatidae, Extant). (E) Adult skull demonstrating the presence of osteoderms. Osteoderms from the left lateral surface have been removed to reveal the underlying cranial elements. Heloderma horridum osteoderms stained with Masson's trichrome (F,H) and toluidine blue (G). Similar to Tarentola spp., H. horridum skeletally mature osteoderms $(F, G)$ have a superficial collagen-poor region and a basal region composed of compact bone. $(H)$ Skeletally immature osteoderm (white asterisk) demonstrating the earliest stages of mineralization. Note the absence of an osteoblast-rich condensation. This mode of ossification is consistent with bone metaplasia. The superficial region develops later during ontogeny. bh (basal region of bone-rich tissue), sf (Sharpey's fibres), sh (superficial region of unidentified skeletal tissue), stc (stratum compactum of the dermis), sts (stratum superficiale of the dermis). Scale bars: $\mathrm{A}=1 \mathrm{~mm}, \mathrm{C}=0.5 \mathrm{~mm}, \mathrm{D}=50 \mu \mathrm{m}, \mathrm{E}=20 \mathrm{~mm}, \mathrm{~F}-\mathrm{H}=100 \mu \mathrm{m}$.

tetrapods, lepidosaurian osteoderms are nested within the dermis at the interface between the stratum superficiale and the stratum compactum.

Among scleroglossans, osteoderm morphology is often taxonomically informative (Camp, 1923; Estes et al. 1988; Read, 1986; Conrad, 2008). For example, varanid osteoderms have a worm-like or vermiform shape (McDowell \& Bogert, 1954; Erickson et al. 2003), whereas those of most anguids resemble flat, imbricating shingles (Zylberberg \& Castanet, 1985; Levrat-Calviac et al. 1986). A similar squamous morphology is also common to the osteoderms of scincids and cordyliforms. However, these elements differ from those of anguids in having a distinctive fractured appearance (Fig. 5A,B), and hence are sometimes referred to as compound osteoderms (Otto, 1909; Camp, 1923; Estes et al. 1988; Greer, 1989; Zylberberg et al. 1992). Osteoderms from various taxa may also develop an intrinsic system of ramifying neurovascular canals [e.g. gerrhosaurids, diploglossine anguids, the gekkonid Tarentola (Geckonia) chalaziae, the anguimorphan Lanthanotus borneensis; see Schmidt, 1912; Strahm \& Schwartz, 1977; Bauer \& Russell,
1989; Maisano et al. 2002]. Although not fully understood, these branching patterns are also hypothesized to have phylogenetic significance. Additional variation is observed in pattern, tissue structure, and possibly mode of skeletogenesis. To draw attention to these differences, the following section discusses each of the three best documented osteoderm-bearing taxa separately.

Gekkonidae (Gekkota). Osteoderms have been welldocumented for the gekkotan Tarentola (Otto, 1909; Parker, 1942; Loveridge, 1947; Levrat-Calviac, 1986-1987; LevratCalviac et al. 1986; Levrat-Calviac \& Zylberberg, 1986; Bauer \& Russell, 1989). In some species (e.g. T. annularis), reinforcement of the dermis by osteoderms is remarkably pervasive, consisting of numerous small $(40-150 \mu \mathrm{m})$, granule-like elements (Fig. 5C) distributed across most of the body (Parker, 1942; Bauer \& Russell, 1989). For others (T. neglecta), the distribution of osteoderms is limited to the dorsal surface of the head, body, tail and proximal portions of the limbs (Levrat-Calviac, 1986-1987). Characteristic of all, only the head demonstrates any direct correspondence 
between osteoderms and epidermal scales; postcranially, multiple osteoderms underpin each scale (Fig. 5D; Parker, 1942; Levrat-Calviac \& Zylberberg, 1986; Bauer \& Russell, 1989).

In section, Tarentola mauritanica osteoderms have two distinct layers (Moss, 1969; Zylberberg \& Castanet, 1985; Levrat-Calviac et al. 1986; Levrat-Calviac \& Zylberberg, 1986), both of which are firmly anchored to the surrounding dermis by Sharpey's fibres (Fig. 5D). The superficial-most layer is a thin, avascular and acellular, collagen-poor, microfibrillar matrix (Levrat-Calviac \& Zylberberg, 1986). Histochemically, this region is positive for acid glycosaminoglycans and, using transmission electron microscopy of demineralized samples, demonstrates periodic electron-dense lines comparable with resting lines (de Ricqlès et al. 1991). The crystalline arrangement is comparable with spheritic mineralization. At present the identity of this unnamed superficial tissue remains unclear, although it appears to share several features in common with superficial odontogenic tissues (enameloid, hyaloine, or ganoine) described in some integumentary elements of non-tetrapods (see Sire et al. 2009, this volume).

The majority of the osteoderm is lamellar bone, nested at the interface between the two layers of the dermis and may become partially embedded within the stratum compactum. Unlike the superficial layer, this basal bony layer demonstrates inotropic mineralization.

To date, the development of gekkotan osteoderms has yet to be investigated. However, based on the structural continuity between the tissue matrix of the adult osteoderm and the surrounding dermis, Levrat-Calviac and colleagues suggest that the development of this region occurs via metaplastic ossification (Levrat-Calviac, 1986-1987; LevratCalviac \& Zylberberg, 1986; Levrat-Calviac et al. 1986).

Helodermatidae (Anguimorpha). Helodermatid osteoderms are robust, bead-like elements developing across the dorsolateral surfaces of the head, the body, tail, and parts of the limbs (Fig. 5E). Morphologically similar elements are found in glyptosaurine anguids, xenosaurids, and the extinct anguimorph genus Carusia (Camp, 1923; Gao \& Norell 2000; Conrad, 2008). Following skeletal maturity, fusion may occur between the overlying osteoderms and underlying elements of the dermatocranium via the gradual extension of mineralization through the stratum compactum that separates the two entities; in situ mineralization transforms the area between the dermatocranium and the osteoderm directly into a mineralized connection (Moss, 1969). Each helodermatid osteoderm corresponds to a single overlying epidermal scale.

Histologically, each helodermatid osteoderm is a heterogeneous blend of bone and dense irregular connective tissues demonstrating variable degrees of mineralization (Moss, 1969). The ossified tissue may be woven-fibred, parallel-fibred or lamellar, and is most commonly associated with vascular canals and areas of remodeling (Fig. 5F). As in Tarentola spp., helodermatid osteoderms are capped by an enigmatic tissue comparable with enameloid or ganoine (Moss, 1969; Smith \& Hall, 1990). This region is thin, avascular, cell-poor, collagen-poor, and is positive for both glycogen and glycosaminoglycans (Moss, 1969) (Fig. 5G). The deepest (basal) margin of the osteoderm directly merges into the stratum compactum of the dermis.

Osteoderms are one of the last skeletal elements to develop in helodermatids. Prior to their formation, the stratum superficiale has already conformed to the osteoderm pattern observed in adults, establishing a series of collagenrich dome-like protrusions underpinning the epidermal scales. Skeletogenesis takes place without the formation of a cell condensation (Fig. 5H). Instead, centres of diffuse mineralization (the osteoderm primordium) appear within each collagen-rich dome. Mineralization is not present at this early stage, but it gradually occurs as the osteoderm extends in the dermis. Moss (1969) observed that this mode of ossification was consistent with metaplastic ossification, the direct transformation of the dermis into bone. Skeletogenesis of the superficial tissue layer has yet to be investigated, although it seems likely to be deposited by a retreating front of scleroblasts (Moss, 1969). Across the body, the formation of osteoderms is asynchronous, with the first elements appearing over the head and cervical regions, followed by positions further caudal and lateral.

Anguidae (Anguimorpha). For most anguids, the majority of the head, the body, tail, and limbs are jacketed by thin, imbricated scale-like osteoderms. Individual elements commonly resemble ovoid discs or rectangular plates, with distinctive cranial (overlapped; gliding) and caudal (overlapping) surfaces. The cranial surface is generally unmarked, whereas the caudal surface is often ornamented with various foramina and meandering grooves. Typically, each osteoderm is superimposed by a single epidermal scale.

Details of histological organization are best known for Anguis fragilis (Zylberberg \& Castanet, 1985; Levrat-Calviac et al. 1986). Each osteoderm has a bilaminar composition, with distinctive superficial (= uppermost; Moss, 1969) and basal layers. Both layers contain Sharpey's fibres and demonstrate inotropic mineralization. The superficial layer is thin, localized entirely within the stratum superficiale and contributes primarily to the surface ornamentation. This tissue layer has been identified as woven-fibred bone, and is characterized by abundant loosely organized collagen fibrils and neutral glycosaminoglycans (Zylberberg \& Castanet, 1985; Levrat-Calviac et al. 1986). Furthermore, it is slightly more radio-opaque than the basal layer.

Compared to the superficial layer, the basal portion is relatively thicker, forming the majority of the osteoderm, 
and is embedded (at least in part) within the stratum compactum. It has been identified as lamellar bone, consisting of a highly organized matrix of orthogonally arranged collagen lamellae (Zylberberg \& Castanet, 1985).

The pattern and mode of anguid osteoderm skeletogenesis is incompletely known. As evidenced in radiographs of juvenile $A$. fragilis, mineralized osteoderms are absent in subadults (individuals less than $35 \%$ adult length; Zylberberg \& Castanet, 1985). Osteoderms reportedly begin to develop within the deep dermis, first appearing as homogeneous, osteoblast-rich condensations (Zylberberg \& Castanet, 1985). This mode of development is consistent with intramembranous ossification (cf. Dasypus: Vickaryous \& Hall, 2006; see below). However, evidence gleaned from both transmission electron microscopy and vital labeling using fluoromarkers indicates that the preexisting dermis is gradually mineralized, suggesting skeletogenesis via metaplastic ossification (Zylberberg \& Castanet, 1985). Alternatively, both processes may contribute. Zylberberg \& Castanet (1985) proposed that the differences in the histology and histochemistry of the two regions may be due to differences in the pre-existing configuration of the dermis, i.e. the strata superficiale and compactum.

Synapsida. Compared with reptiles, osteoderms are rare among synapsids. In addition to xenarthrans, only two osteoderm-bearing species have been described: the Late Permian (260 Ma) varanopids Heleosaurus scholtzi (BothaBrink \& Modesto, 2007; Reisz \& Modesto, 2007) and Elliotsmithia longiceps (Reisz et al. 1998). (It should be noted that these species are possibly synonymous; Botha-Brink \& Modesto, 2007). Varanopid osteoderms have a block-like morphology, and are organized into multiple transverse rows in the cervical and pectoral regions (Botha-Brink \& Modesto, 2007) (Fig. 6A,B).

Among xenarthans, osteoderms are present in several species of mylodontid (ground) sloths and in all Cingulata, a clade consisting of pampatheres, glyptodonts and armadillos (Gaudin \& Wible, 2006; Hill, 2006). Individual osteoderms of skeletally mature cingulates are organized into tightly articulating mosaics or shields reinforcing the dermis in the dorsal and lateral surfaces of the head, body and tail. Across the body, these shields connect to create a carapace. In armadillos (presently considered a paraphyletic group; Gaudin \& Wible, 2006) and pampatheres, the carapace includes an imbricated series of transverse bands (the banded shield) spanning between the pectoral and pelvic apparatuses, permitting a degree of flexibility (Wilson, 1914; Cooper, 1930; Vickaryous \& Hall, 2006). In glyptodontids the banded shield is absent and the entire carapace forms a tightly sutured and presumably immobile unit (Gaudin \& Wible, 2006; Hill, 2006). In some glyptodontids the shield encasing the tail ends distally in a bulbous collection of osteoderms fused to form a club.
Most cingulatan osteoderms conform to either a rectangular or polygonal (pentagonal and hexagonal) morphology (Fig. 6C-F). Rectangular osteoderm imbricate, and have distinctive cranial (overlapped) and caudal (overlapping) regions. Polygonal osteoderms form juxtaposed pavements and lack the lap articulations of the rectangular form.

Skeletally mature cingulatan osteoderms are primarily composed of cellular bone with no evidence of a distinctive capping tissue (Fig. 6G). Compact lamellar bone lines the superficial and deep surfaces, whereas the centre of the element has a cancellous organization (mostly parallel-fibred bone) that grades into Sharpey-fibred bone at the lateral margins (Fig. 6E; Hill, 2006; Vickaryous \& Hall, 2006; Krmpotic et al. 2008). Most of the bony matrix includes various large, unmineralized collagen bundles and neurovascular canals, and evidence of remodeling with the presence of secondary osteons. Histochemically, the matrix stains with various connective tissue protocols, and demonstrates evidence of collagen fibres in tension within the fabric of the Sharpeyfibred bone (Vickaryous \& Hall, 2006).

Details of osteoderm development in armadillos are based primarily on Dasypus novemcinctus (Vickaryous \& Hall, 2006; see also Wilson, 1914; Cooper, 1930). Osteoderm formation begins by the end of the embryogenesis and is asynchronous across the body. Elements first appear in clusters above the pectoral girdle and thoracic vertebrae, followed by the head, pelvic girdle, and finally across the tail (Fig. 6G). Within each of these regional shields, osteoderms first appear craniomedially and sequentially develop in caudal and lateral positions. Across the head shield, osteoderms first appear in the area lying over the frontals and parietal. Prior to parturition, osteoderms are present in each regional shield, although each shield may be incompletely developed (Vickaryous \& Hall, 2006).

Initial osteoderm development begins deep within the stratum superficiale as a discrete aggregation of osteoblasts oriented parallel to the epidermis. Cells of this primordium secrete osteoid (Fig. 6H). With continued centrifugal growth, osteoblasts and collagen bundles from the pre-existing dermis become entrapped and/or incorporated within the osteoderm matrix. Mineralization commences centrally, giving rise to woven-fibred bone. For elements with the rectangular morphology, the caudal region mineralizes prior to the cranial region; polygonal elements ossify centrifugally. As the presumptive osteoderm matures, the distribution of osteoblasts and osteoid becomes polarized, with multiple large cells and thicker osteoid arranged on the superficial surface and few thin cells and less osteoid on the deep surface. The entire element is surrounded by a presumptive periosteum lined by numerous fibroblasts, and an enshrouding collection of osteoblasts. With continued maturation, parallel-fibred bone is deposited, blood vessels are incorporated, and bone remodeling occurs.

The initial mode of osteoderm formation in Dasypus novemcinctus is consistent with intramembranous 

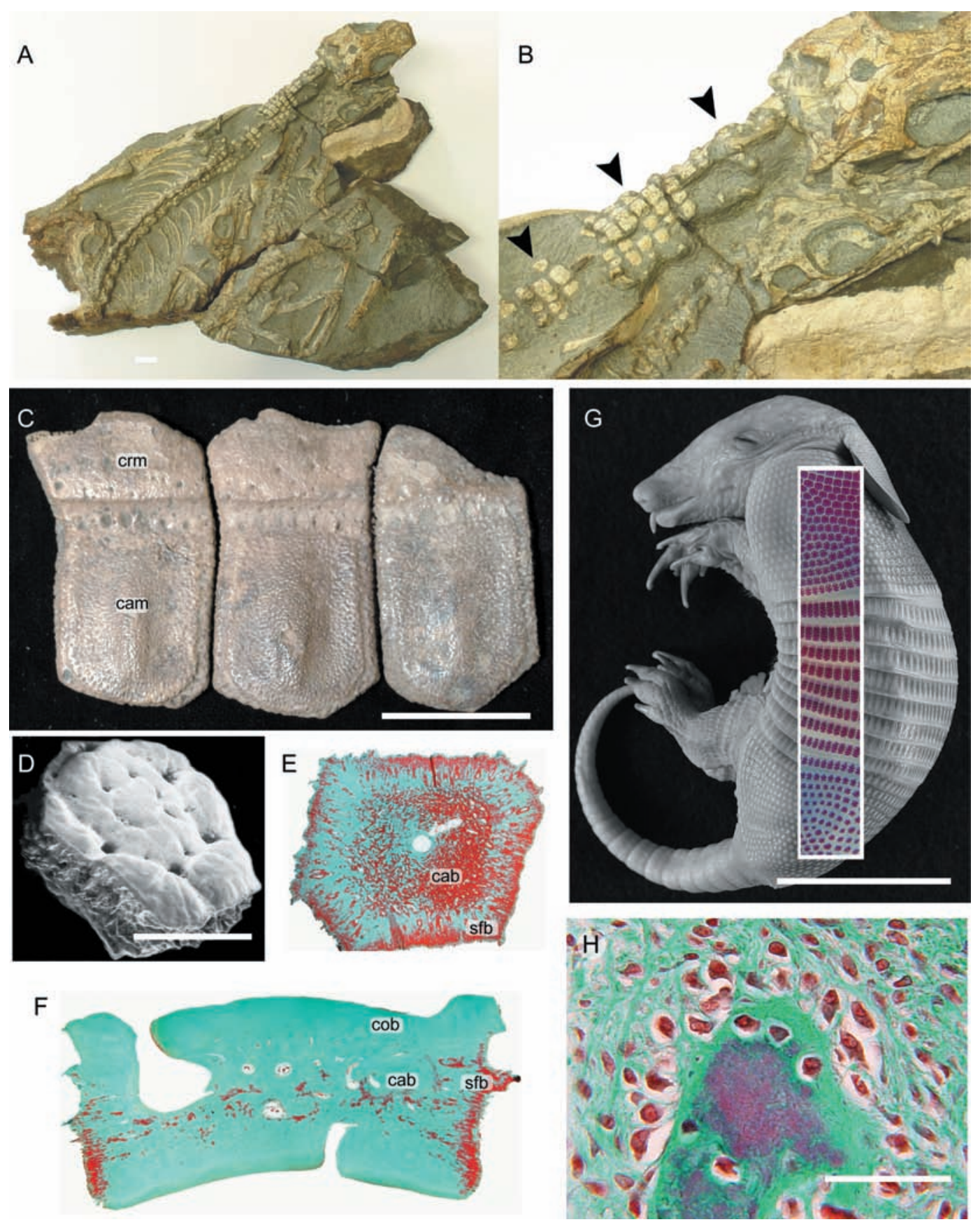

Fig. 6 Synapsid osteoderms. (A,B) Heleosaurus scholtzi (Varanopidae, Permian: Iziko South African Museum of Cape Town SAM-PK-K8305), a rare example of a non-xenarthran osteoderm-bearing synapsid. (A) A fossil specimen consisting of five individuals, with the largest (B) demonstrating in situ osteoderms (black arrowheads) across the cervical region (see Botha-Brink \& Modesto, 2007). (C-H) Morphology and development of osteoderms in xenarthrans. (C) Holmesina occidentalis (Pampatheriidae, Late Pleistocene: Royal Ontario Museum 39257, 40046, 40047). Note the distinctive cranial (overlapped) and caudal (overlapping) margins on each osteoderm. (D-H) Dasypus novemcinctus (structural-grade armadillo, Extant). (D) Scanning electron micrograph of an adult osteoderm with a polygonal morphology. ( $\mathrm{E}, \mathrm{F}, \mathrm{G})$ Osteoderm sections stained with Masson's trichrome. (E) Frontal section demonstrating the development of cancellous bone within the centre of the osteoderm, and Sharpey-fibred bone along the lateral margins. (F) Longitudinal section (dorsal towards the top of the panel) demonstrating the presence of cancellous bone sandwiched between layers of compact bone, and Sharpey-fibred bone at the lateral margins. (G) Late term embryo with Alizarin red single-stained whole-mounted skin superimposed. Development of osteoderms is asynchronous, with the elements first developing over the pectoral apparatus and mid-trunk area before those above the pelvic apparatus. (H) Early mineralization of a presumptive osteoderm, characterized by many large osteoblasts and a thick seam of osteoid. This mode of skeletogenesis is consistent with intramembranous ossification. cab (cancellous bone), cam (caudal margin), cob (compact bone) crm (cranial margin), sfb (Sharpey-fibred bone). Scale bars: $A=1 \mathrm{~mm}, C=40 \mathrm{~mm}, \mathrm{D}=50 \mu \mathrm{m}, \mathrm{E}=20 \mathrm{~mm}, \mathrm{~F}, \mathrm{H}=40 \mu \mathrm{m}, \mathrm{G}=30 \mathrm{~mm}$. Photographs (A,B) courtesy of Dr. Jennifer Botha-Brink, University of the Free State, Bloemfontein, Republic of South Africa. 
ossification: direct bone formation within a condensation of osteoblasts depositing bone matrix without a cartilaginous precursor (Vickaryous \& Hall, 2006). As such, Dasypus osteoderm formation is identical to the mode of skeletogenesis of the dermatocranium.

\section{Carapace}

Testudines. The turtle shell is a skeletal complex composed of a series of osseous elements united into dorsal (carapace) and ventral (plastron) components, and covered by thick epidermal scales or leathery integument. The plastron incorporates homologues of the clavicles and interclavicle (the epiplastra and entoplastron, respectively), as well as a series of intramembranously derived elements comparable with gastralia (Romer, 1956; Zangerl, 1969; Gilbert et al. 2001, 2007; Cebra-Thomas et al. 2007). The carapace integrates elements of the endoskeleton (vertebrae and ribs) with a mosaic of dermal bones characterized as either thecal or epithecal elements. Thecal elements develop relatively early during skeletogenesis and are by far the most common source of the carapace. The thecal-derived carapace (Fig. 7A) includes neural bones (unpaired, capping the neural spine of the underlying dorsal vertebrae),

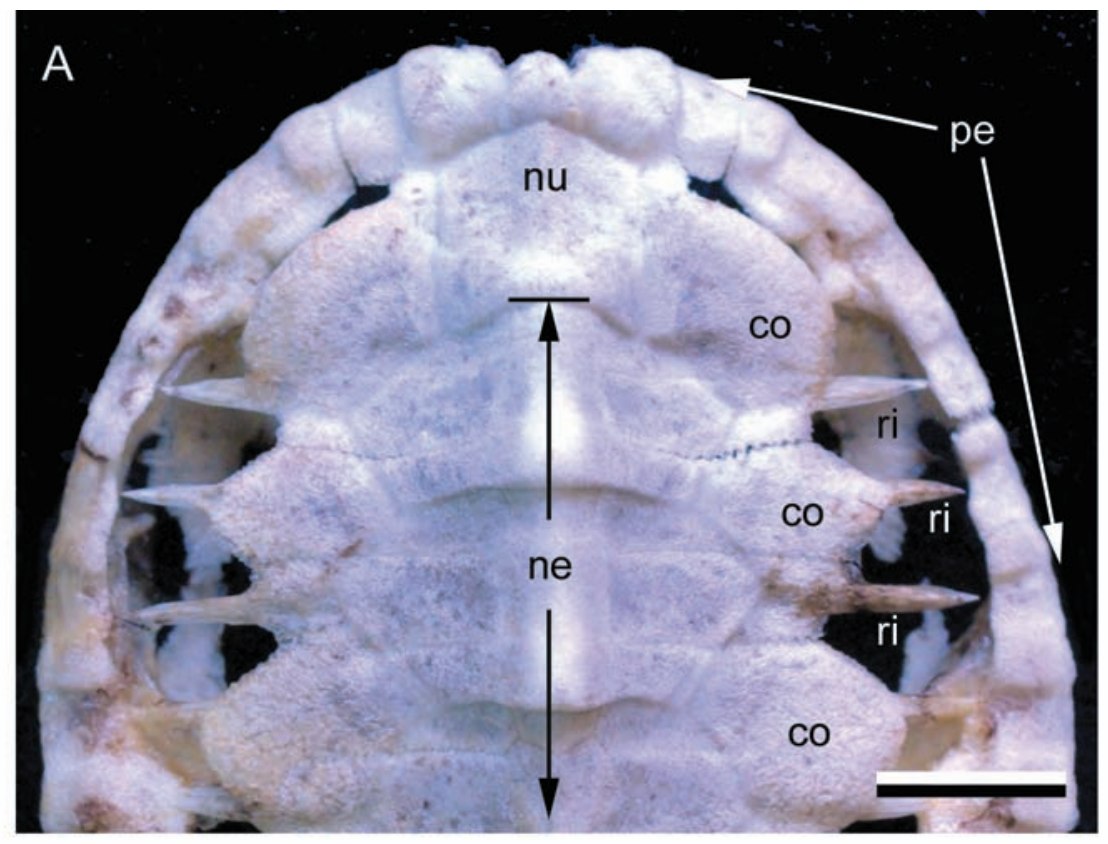

B

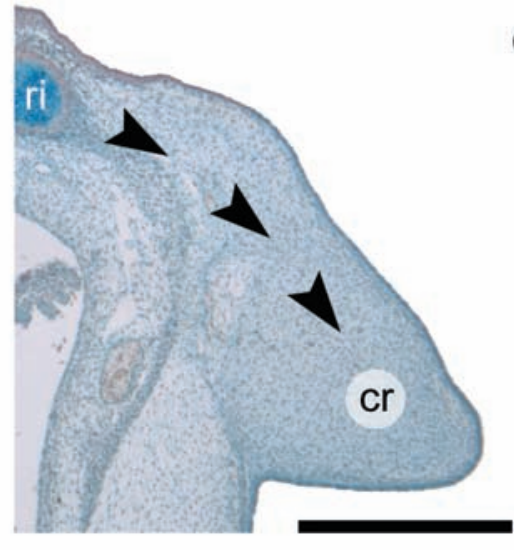

C

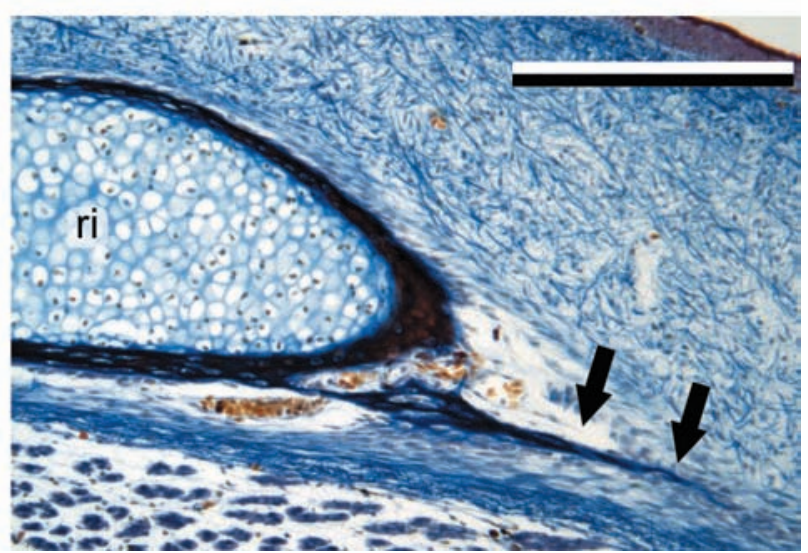

Fig. 7 Turtle carapace. (A) Trachemys scripta (Cryptodira, Extant). Dorsal view of the cranial portion of a subadult carapace. As for most turtles, the carapace of $T$. scripta is composed of a complex of dermal (thecal) elements, ribs, and vertebrae. (B,C) Chelydra serpentina embryos (Cryptodira, Extant), serially sectioned. (B) Yntema stage 16, stained with Celestine blue and Direct red (the Hall-Brunt Quadruple stain). Cells of the carapacial ridge synthesize fibroblast growth factors, attracting the developing rib and drawing it into the future dermis (indicated by black arrow heads). (C) Yntema stage 22, stained with Mallory's trichrome. The developing rib is now firmly invested within the dermis. Note the development of an intramembranously derived bony spicule (black arrows). The adjacent rib is undergoing perichondral ossification. co (costal bone), cr (carapacial ridge), ne (neural bone), nu (nuchal bone), pe (peripheral bone), ri (rib). Scale bars: $A=10 \mathrm{~mm}, \mathrm{~B}=500 \mu \mathrm{m}, \mathrm{C}=400 \mu \mathrm{m}$. 
costal bones (paired, associated with the underlying ribs), peripheral bones (paired, articulating at the distal margin of the costal bones to create the lateral margin of the carapace), suprapygal and pygal bones (unpaired, articulating with the costals and peripherals at the caudal margin of the carapace) and the nuchal bone (unpaired, articulating with the costals and peripherals at the cranial margin of the carapace). In some aquatic and marine taxa, however, the thecal contribution to the carapace is diminished, coinciding with the delayed formation of a more superficial series of carapacial mineralizations, the epithecal elements (Zangerl, 1939, 1969). The epithecal-derived carapace is best demonstrated by Dermochelys coriacea (the leatherback turtle). In D. coriacea the carapace is composed of large numbers of irregular interlocking epithecal contributions, with only a single thecal contribution - the nuchal bone (Gadow, 1901; Deraniyagala, 1939; Zangerl, 1939). Epithecal elements are also reported in some fossil marine taxa (Zangerl, 1969). In addition to the carapace and plastron, turtles may further reinforce the integument with postcranial osteoderms (= granicones) developing across the neck, limbs and tail (Gaffney, 1990, 1996; Barrett et al. 2002).

Histologically, the skeletally mature carapace is a trilaminar structure comparable with diploe (Scheyer \& SanchezVillagra, 2007; Scheyer \& Sander, 2007; Scheyer et al. 2007). In general, the external and internal cortices (= superficial and deep carapacial surfaces; outer and inner tables) are composed of compact lamellar bone with moderate amounts of vascularization. Nested between the external and internal cortices is a central cancellous region (Zangerl, 1969; Scheyer \& Sanchez-Villagra, 2007; Scheyer \& Sander, 2007; Scheyer et al. 2007). Detailed descriptions of tissue structure and organization indicate that the histology of the carapace is often taxonomically informative. For example, the external cortex of trionychids has a unique skeletal architecture consisting of a plywood-like structural arrangement of collagen fibrils (Scheyer et al. 2007). Less is known about the histological structural of epithecal elements and turtle osteoderms. A sectioned epithecal element from Dermochelys coriacea demonstrates an extensive central cancellous cavity, with almost no compact bone lining the external and internal cortices (Meylan, 1987). From what is known, the histology of turtle osteoderms appears to be comparable with those of archosaurs: a compact cortex and a cancellous core, composed of woven-fibred and parallel-fibred (fibrolamellar) bone with evidence of remodeling (Barrett et al. 2002).

The origin of the thecal-derived carapace has often been portrayed as the fusion of osteoderms with ribs and vertebrae (Owen 1849; Hay 1898; Romer, 1956; Lee, 1997). However, more recent analyses have since demonstrated that the developmental origin is considerably more complicated. Development of the carapace begins early in the embryonic period (e.g. Yntema stage 14 in Chelydra serpentina and Trachemys scripta) with the formation of the carapacial ridge, a bulge of mesenchyme located between (and dorsal to) the fore and hindlimb buds (Fig. 7B; Gilbert et al. 2001; Nagashima et al. 2005; Moustakas, 2008). As this mesenchyme begins to differentiate (forming the dermis), some intrinsic cells synthesize fibroblast growth factors (FGFs). The presence of FGFs attracts the cell condensations representing the future ribs (Gilbert et al. 2001, 2007), directing these elements laterally into the dermis, and not ventrally as in other tetrapods. The cells of the developing ribs then secrete bone morphogenetic proteins (BMPs), which induces localized perichondral ossification. As the ribs begin to ossify, spicules of bone develop intramembranously within the surrounding dermis (Fig. 7C; Gilbert et al. 2001, 2007; Cebra-Thomas et al. 2007). This combination of rib and dermis ossification results in the formation of the costal elements. A similar mode of formation is hypothesized to give rise to the neural elements (Rieppel \& Reisz, 1999). Competence of the dermis to respond to BMPs is consistent with the conditions observed in various connective tissue diseases linked to BMP overexpression and ectopic bone formation (Shafritz et al. 1996; Cebra-Thomas et al. 2007). Full mineralization of the costals and neurals takes place posthatching.

In contrast to the costal and neural, the nuchal bone is not directly associated with any developing element of the endoskeleton. Shortly after the formation of the carapacial ridge (Yntema stage 20-21), it begins as unpaired cell condensation within the differentiating dermis at the cranial margin of the presumptive carapace. Continued development of the nuchal bone occurs via intramembranous ossification, with the deposition of osteoid followed by calcified (Gilbert et al. 2007). A similar mode of ossification is common to the dermatocranium, elements of the plastron, and osteoderms of the synapsid Dasypus novemcinctus. It is suggested that the suprapygals, pygals, and peripherals also undergo a similar mode of development (Rieppel, 2001).

Details of epithecal element formation are less clear, although it is hypothesized that they are unequivocal osteoderms (Rieppel, 2001). An osteodermal identification is consistent with the relatively late development of epithecal elements (following the formation of the thecal elements), and their formation embedded within the dermis.

Placodonts. Placodonts are an extinct lineage of marine reptiles that lived during the Triassic period (250-205 Ma). Among basal members of the group, osteoderms are either absent (e.g. Paraplacodus broilii) or modestly developed as a single sagittal row superimposed above the dorsal vertebrae (Placodus gigas) (Rieppel, 2002; Scheyer, 2007). Among more deeply nested cyamodontoid placodonts, large numbers of osteoderms form within the integument, creating a broad mosaic of juxtaposed 
A

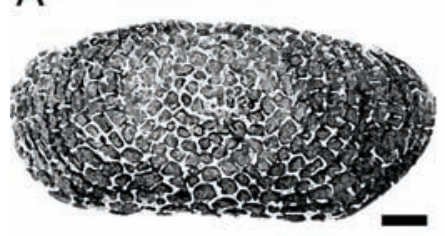

B

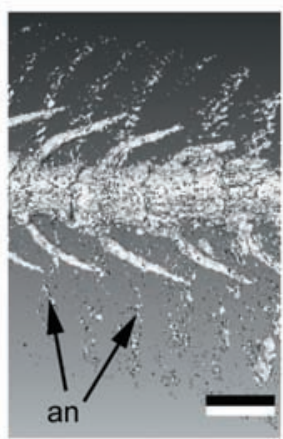

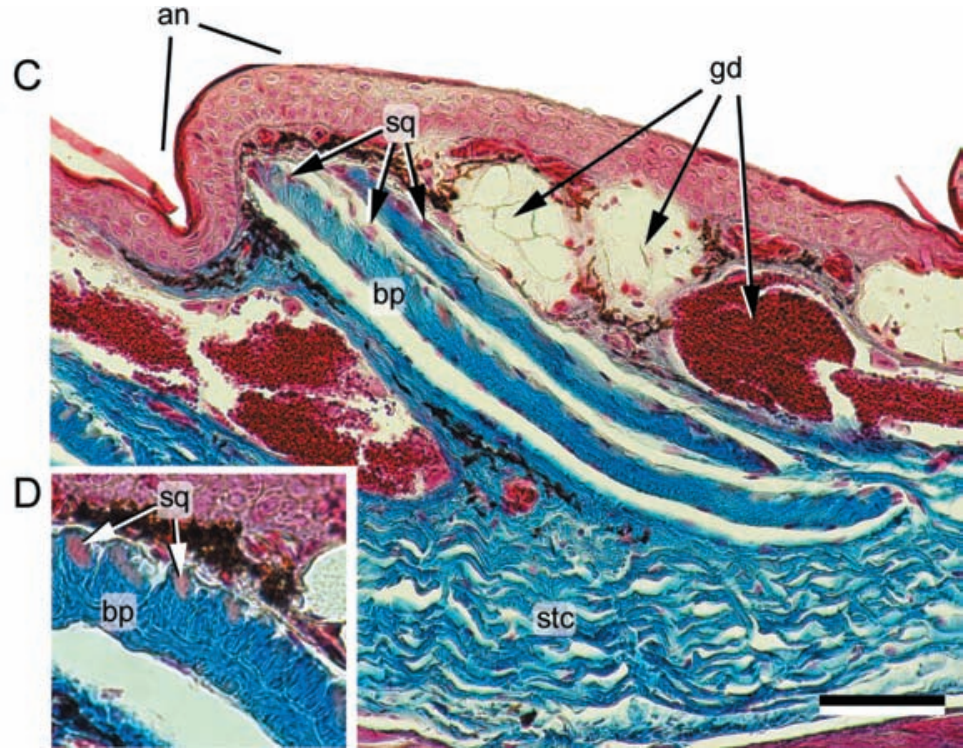

Fig. 8 Gymnophionan dermal scale. (A) Schematic dermal scale in dorsal view (modified from Zylberberg \& Wake, 1990) demonstrating the presence of numerous irregularly shaped squamulae across the dorsal surface. (B) Dermophis mexicanus (Caeciliidae, Extant) computed tomographic rendering of a segment of the trunk demonstrating the presence of dermal scales within the dorsal integument. Note the correspondence between annuli (body rings) and concentrations of dermal scales. (C) Caecilia thompsoni (Caeciliidae, Extant), longitudinal section of the integument (dorsal towards the top), Mallory's azan staining. Each dermal scale resides within a separate connective tissue pocket, with multiple scale-bearing pockets nested in a connective tissue pouch. Adjacent to the pocket are various glands. an (annulus), bp (basal plate), gd (gland), sq (squamula), stc (stratum compactum of the dermis). Scale bar: $A=200 \mu \mathrm{m}, B=2 \mathrm{~mm}, C=100 \mu \mathrm{m}$. Specimens (B,C) courtesy of Dr. M. Wake, University of California, Berkeley, CA, USA.

mineralized elements that combine to resemble a turtle carapace (Rieppel, 2002; Naish, 2004; Scheyer, 2007). However, unlike turtles (but similar to some cingulatan mammals), the placodont carapace does not integrate the ribs or vertebrae and thus the resemblance is strictly superficial.

Isolated osteoderms from basal placodonts are composed of compact bone without a cancellous core. Most of the tissue has a parallel-fibred and lamellar bone grade of organization, and the cortex demonstrates evidence of periodic deposition and incorporated Sharpey's fibres (Scheyer, 2007). In some cyamodontoids, the mineralized tissues of the carapace include regions with many large, spherical lacunae, sometimes aligned in what are described as isogenous groups. These tissues have a comparable structure to fibrocartilage (Scheyer, 2007). Alternatively, it has been noted that the loss of unmineralized fibrous tissue from dried osteoderms and fossil specimens may lead to the confusing appearance of large 'lacunae' (Moss, 1969). Hence it is possible that the putative lacunae represent spaces where unmineralized large diameter collagen bundles once penetrated.

Based on a limited number of subadult (juvenile) specimens, placodont osteoderms appear to develop relatively late during development (post-embryonic period) (Rieppel, 2002). The carapace forms from a series of incompletely mineralized elements that coalesce asynchronously, in a cranial to caudal fashion.

\section{Dermal scales}

Dermal scales are integumentary elements unique to the 'amphibian' lineage Gymnophiona. Skeletally mature dermal scales are flat, disc-like elements obliquely oriented within the dermis. Each dermal scale is isolated within a thin connective tissue pocket (Fig. 8). Multiple scale-bearing pockets lie within a larger connective tissue pouch, and each pouch is associated with an annulus (body ring), nested among various skin glands deep to the epidermis (Zylberberg \& Wake, 1990). Dermal scales are most pervasively developed among basal taxa (e.g. Ichthyophis spp.), with a strong trend towards reduction in phylogenetically more deeply nested forms (e.g. scolecomorphids; Zylberberg \& Wake, 1990). On the basis of gross morphology it has been reported that dermal scales are also present among members of the fossil amphibian group Temnospondyli (e.g. Castanet et al. 2003; Witzmann, 2007), although there is presently no histological data to support this.

Overall, little is known about dermal scale formation. Unlike osteoderms, in gymnophionans dermal scales are not composed of bone. Instead the histological organization includes a basal plate composed of unmineralized collagen lamellae arranged into a plywood-like tissue, superimposed by a discontinuous layer of squamulae (Zylberberg et al. 1980; Zylberberg \& Wake, 1990). Each squamula is an aggregation of mineralized globules and mineralized collagen fibres (Zylberberg \& Wake, 1990). Squamulae 

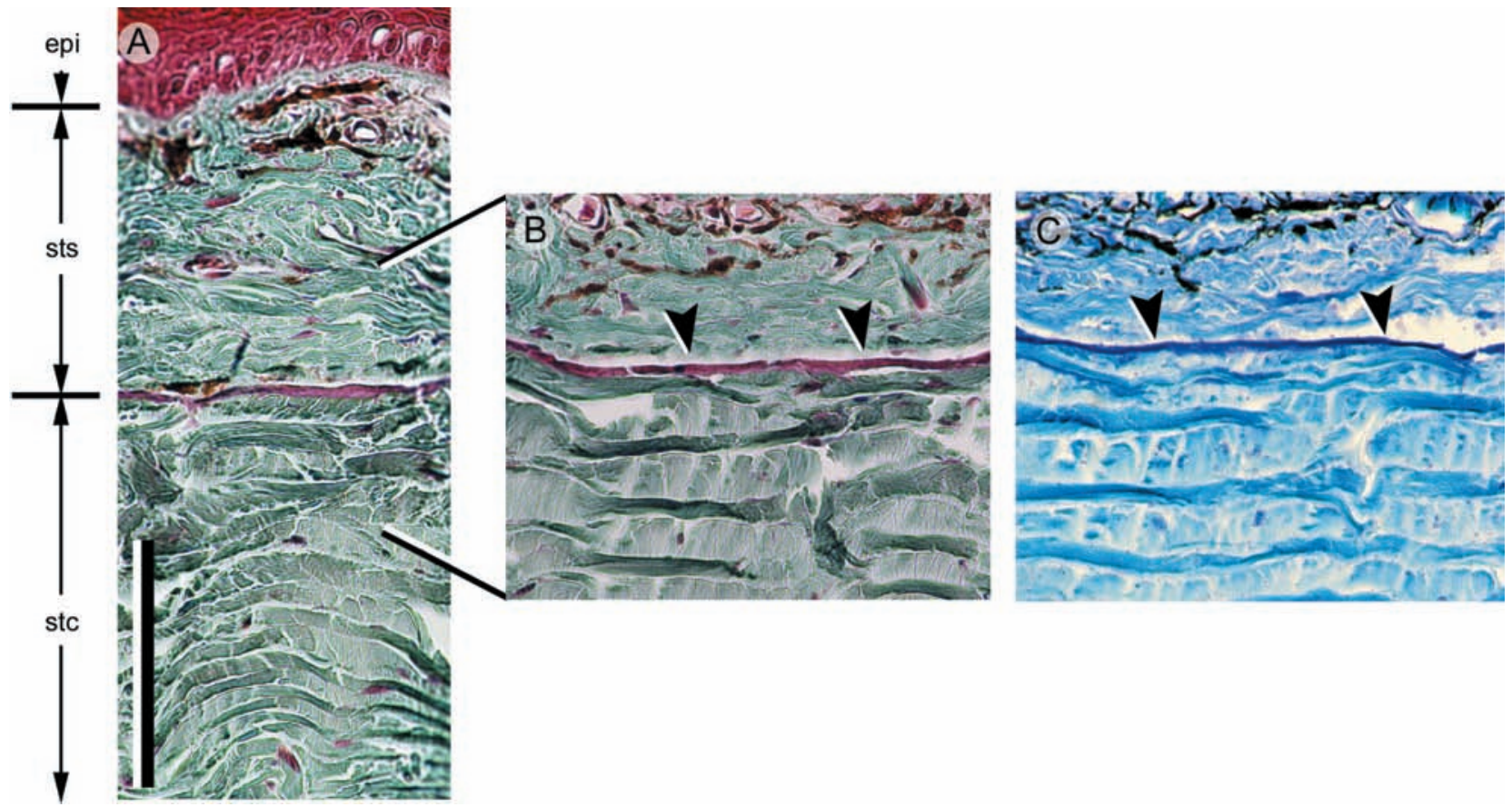

Fig. 9 Anuran lamina calcarea. (A-C) Bufo borealis (Bufonidae, Extant: University of Calgary Museum of Zoology/Amphibia 1975.30). Longitudinal sections (dorsal towards the top), stained with $(A, B)$ Masson's trichrome and $(C)$ toluidine blue. The lamina calcarea is situated at the interface between the stratum superficiale and the stratum compactum (black arrowheads). It lacks intrinsic cells and collagen fibres, and stains positive for glycosaminoglycans. Scale bar: $100 \mu \mathrm{m}$. Specimens courtesy of W. Fitch, University of Calgary, Calgary, Canada.

demonstrate spherical mineralization of a loosely structured organic matrix, with various scattered, spherical osteoblast-like cells (Castanet et al. 2003). The basal plate is largely acellular and appears to be deposited by a retreating front of scleroblasts lining the deep surface of the dermal scale (Zylberberg et al. 1980; Zylberberg \& Wake, 1990). Based on structural similarities and a common phylogenetic origin, this lamellar tissue may be homologous with elasmodine of the elasmoid scales of aquatic sarcopterygians (coelacanths and lungfish; see Sire et al. 2009, this volume).

\section{Lamina calcarea}

Whereas true osteoderms (i.e. those consisting of bone) are relatively rare among anurans, many taxa, particularly terrestrial forms (e.g. bufonids), develop an unusual intradermal layer composed of acellular mineralized tissue - the lamina calcarea [Muzii, 1968; = ground substance layer (Elkan, 1976); amorphous layer (Sampson et al. 1987); Eberth-Kastschenko layer (Katchburian et al. 2001); substantia amorpha (Schwinger et al. 2001)]. The lamina calcarea has been documented in a wide diversity of species, including various discoglossids, pelobatids, microhylids, ranids, bufonids, 'hylids', dendrobatids, and ceratophyrines (Elkan, 1976; Toledo \& Jared, 1993). In some ceratophyrines and leptodactylids, the thin, almost continuous lamina calcarea is segmented into numerous granular bodies known as dermolita [Muzii, 1968; = granules of the substantia amorpha (Verhaagh \& Greven, 1982; see also Sampson et al. 1987)]. It remains unclear if the lamina calcarea/dermolita and osteoderms can both develop within the same individual and what (if any) evolutionary relationship exists between them. Whereas osteoderms are cellular and collagen-rich, the lamina calcarea (and dermolita) is (are) acellular and lack(s) intrinsic collagen (Fig. 9). However, all of these elements occupy a similar position within the dermis (at the interface between the stratum superficiale and stratum compactum), are anchored by Sharpey's fibres, and consist of a matrix that includes proteoglycans, glycosaminoglycans, and inorganic electron dense calcium phosphates comparable to hydroxyapatite crystals (Taylor et al. 1966; Muzii, 1968; Sampson et al. 1987; Toledo \& Jared, 1993; Katchburian et al. 2001).

Little is known about the development of the lamina calcarea. It is hypothesized that fibroblasts are involved in both the production of the organic phase and its mineralization (Toledo \& Jared, 1993; see also Verhaagh \& Greven, 1982). Unlike osteoderms that develop only after metamorphosis, the lamina calcarea has been observed in both tadpoles and adults (e.g. in the ranid Rana catesbeiana: Taylor et al. 1966). 


\section{Origin and evolution of the integumentary skeleton in vertebrates}

\section{Origin of the integumentary skeleton and the (probable) role of the neural crest}

The embryological origin of the vertebrate integumentary skeleton remains incompletely understood, although a significant role for the neural crest is widely suspected (Moss, 1969; Smith \& Hall, 1990). Building on observations of tooth formation, Moss (1969) hypothesized '... all dermal sclerifications (= integumentary skeletal elements) are formed as the result of a mutually inductive interaction between ectomesenchymal cells, derived from the neural crest, and the basal layer of the epidermis' (p. 528). Whereas direct evidence in the form of lineage tracing of elements such as osteoderms, dermal scales and the lamina calcarea remains wanting, the neural crest hypothesis is clearly consistent with available data. For example, it is well-established that neural crest cells contribute to both the dermal skeleton (craniofacial bone, teeth, and the caudal fin rays of teleosts) and the integument, including craniofacial dermis and all pigment cells outside the retina (Mauger, 1972a,b; Le Lièvre \& Le Douarin, 1975; Gans \& Northcutt, 1983; Lumsden, 1987, 1988; Hall \& Hörstadius, 1988; Couly et al. 1993; Smith et al. 1994; Hall, 1999; Dhouailly et al. 2004; Tosney, 2004; Creuzet et al. 2005). Related to this, experimental studies on tetrapods lacking integumentary skeletons (e.g. Ambystoma mexicanum, Mus musculus) have revealed that transplanted postcranial (trunk) neural crest cells retain (albeit limited) odontogenic potential (Lumsden, 1987, 1988; Graveson et al. 1987). More recently, work by Gilbert and colleagues on the turtle Trachemys scripta noted that various cell markers characteristic of skeletogenic neural crest cells (positive reactions for HNK-1, PDGFR $\alpha$, p75, and FoxD3) are also expressed by the cells giving rise to the cranial-most element of the carapace, the nuchal bone (Cebra-Thomas et al. 2007; Gilbert et al. 2007; see also Clark et al. 2001). Furthermore, it is also worth noting that neural crest cells (e.g. melanoblasts) are invasive and able to migrate within the developing dermis to colonize positions across the body (Moss, 1969; Hall \& Hörstadius, 1988; Tosney, 2004).

Additional support is gleaned from the fossil record. Based on comparisons with extant skeletal tissues, it is reasonable to accept that the odontogenic- and osteogenicrich integumentary skeletons of early stem gnathotomes (e.g. dentine, cementum, bone) were derived from the neural crest (Smith \& Hall, 1990; see also Donoghue et al. 2006). Given the near continuous body-wide coverage of these integumentary elements in many early forms, it is also reasonable to predict that both cephalic and trunk neural crest populations contributed to the formation of these mineralized tissues (Smith \& Hall, 1990). By extension, it is hypothesized that cephalic and trunk neural crest cell populations of basal actinopterygians and basal sarcopterygians retain the ability to form odontogenic and osteogenic tissues, giving rise to ganoid and cosmoid scales, respectively. Future developmental studies of extant basal actinopterygians (e.g. polypteriforms) provide an obvious target for testing this proposal.

\section{Osteoderm evolution and development in tetrapods}

Available evidence clearly supports osteoderms as plesiomorphic for tetrapods, evolving from the ancestral cosmoid scale following the loss of odontogenic tissues and the ramifying pore-canal system. Among modern taxa, osteoderms demonstrate considerable variation both morphologically and structurally, and yet with rare exceptions there is often no clear correspondence between ecology or integumentary function and the presence and development of these elements. Combined with an inconsistent phylogenetic distribution, there seems to be little doubt that the phenotypic manifestation of osteoderms is lineage-specific (Zylberberg \& Wake, 1990). Fundamentally, however, all osteoderms share: (1) a common origin within the dermis, developing at the interface between the stratum superficiale and stratum compactum, or exclusively within the stratum superficiale adjacent to this contact; and (2) a structural composition principally consisting of osseous tissue without the formation of an odontogenic cell population (odontogenic papilla) or cartilage (with the possible exception of placodonts). Based on the above, there is strong evidence that all osteoderms are unambiguously derivatives of the dermal skeletal system and thus all osteoderms share a common evolutionary origin.

It is commonly suggested that osteoderms develop via metaplastic ossification, the direct transformation of the dermis into skeletal tissue (viz. bone) without differentiation of osteoblasts (e.g. Ruibal \& Shoemaker, 1984; Levrat-Calviac \& Zylberberg, 1986; Scheyer \& Sander, 2004; Main et al. 2005). In many instances, however, this ontogenetic explanation is made in the absence of developmental data and based solely on the histological organization of the skeletally mature organ. It is therefore significant that several recent investigations have since demonstrated that osteoderms do not necessarily (or exclusively) employ this modality. For example, osteoderms of the nine-banded armadillo, Dasypus novemcinctus, initiate development via intramembranous ossification (Vickaryous \& Hall, 2006). In the American alligator, Alligator mississippiensis, the osteoderm primordium begins as an accumulation of dense irregular connective tissue that initially mineralizes without the formation of bone (Vickaryous \& Hall, 2008). A similar mode of skeletogenesis has also been described for osteoderms of the beaded lizard, Heloderma horridum (Moss, 1969). Thus although metaplastic ossification may certainly contribute to osteoderm ossification and growth, it is not necessarily the only mode of development. 
Across the dorsolateral body surface, clusters of adjacent osteoderms may tightly articulate or even fuse with one another to create a unified skeletal mosaic dorsal to the vertebral column and rib cage (e.g. Dasypus novemcinctus, placodonts). Predictably this has led to the hypothesis of the turtle carapace as equivalent to the unification of osteoderms with the endoskeleton (e.g. Owen, 1849; Lee, 1997; Joyce et al., 2008; Scheyer et al., 2008). Recently, however, a newly described fossil that lacks osteoderms has been proposed as an ancestral turtle (Odontochelys semitestacea; Li et al. 2008). Intriguingly, the carapacial skeleton of Odontochelys closely resembles that of modern turtle embryos prior to the complete development of the shell. Based on the above evidence it has been hypothesized that the carapace did not evolve from the fusion of osteoderms (Li et al. 2008). Although the specific details of carapace origin remain controversial, we note that available data clearly supports a fundamental evolutionary relationship between the skin (viz. the dermis) and skeleton. In addition to providing a skeleto-competent matrix environment and acting as the source of osteogenic cells, the dermis is also involved in redirecting rib growth. It is also worth noting that the intramembranous mode of ossification characteristic of carapace elements such as the nuchal bone is comparable to osteoderm formation in modern armadillo-grade xenarthrans.

\section{A revised scenario for the evolution and diversification of the integumentary skeleton in tetrapods}

A revised scenario for the evolution of the tetrapod integumentary skeleton is presented (Fig. 10), building upon the updated hypothesis of integumentary skeleton evolution in non-tetrapods (Sire et al. 2009, this volume). As for all osteichthyans, tetrapod integumentary elements share a common ancestry with the neural crest-derived rhombic scale. This plesiomorphic element is understood to be composed of four stratified tissue types similar to the ganoid scale of modern polypteroid actinopterygians. From superficial to deep these include: ganoine (= enamel); dentine (= woven-fibred dentine); elasmodine (= lamellar dentine); and bone (woven-fibred, parallel-fibred or lamellar). The overlying dental tissues (ganoine, dentine, and elasmodine) are derivatives of odontogenic neural crest cells, whereas those of the bony base are from a separate osteogenic neural crest population (Smith \& Hall, 1990, 1993). Among basal sarcopterygians and digitbearing stem tetrapods (tetrapodomorphs), both neural crest populations are active, giving rise to the cosmoid scale. Among osteoderm-bearing tetrapods the odontogenic population, or the odontogenic competency of these cells, is lost. And while the osteogenic population is generally preserved, it is often quiescent. Consequently, we propose that the ability of tetrapods to form osteoderms is frequently present but latent (not expressed).

The lineage-specific phenotypic diversity and discontinuous phylogenetic distribution are consistent with the hypothesis that osteoderm formation is associated with structural properties of the dermis, as an extracellular matrix environment conducive to skeletal formation, and the presence of presumptive osteogenic cells (Main et al. 2005; Vickaryous \& Hall, 2008). Thus a deeper understanding of the integumentary skeleton lies not with the skeleton per se, but with the integument. Related to this, it is important to note that the latent osteogenic capacity of the dermis is not restricted to tetrapods. Although the majority of teleosts develop elasmoid scales (herein considered derivatives of the odontogenic component of the ancestral scale; Sire et al. 2009, this volume), in some lineages these elements are replaced by bone-rich plates and scutes (e.g. armored catfish, gasterosteids, syngnathids: Sire, 1993; Sire \& Huysseune, 2003). Unlike elasmoid scales, these integumentary investments are considered to be derivatives of the osteogenic ancestral component. Based on these data it may be concluded that osteoderms are an example of deep homology (Main et al. 2005; Hill, 2006; Vickaryous \& Hall, 2008).

The source of the collagen/cell-poor tissue skeletal tissue capping some reptilian osteoderms (e.g. the lepidosaur Heloderma spp.) remains uncertain. However, as there is no evidence of any participation by an odontogenic cell population, it is hypothesized that the overlying epidermal cells have retained the ability to contribute (in polarized fashion) epithelial matrix products similar to the formation of enameloid (Sire et al. 2009, this volume). A similar explanation has been forwarded for the appearance of collagen/cell-poor tissues in some teleosts (limiting layer of elasmoid scales and hyaloine of armored catfish scutes; Sire, 1993; Sire \& Huysseune, 2003; Sire et al. 2009, this volume).

The structure of the gymnophionan dermal scale is completely unlike that of an osteoderm (e.g. dermal scales lack bone), and the two elements are not considered to be equivalent (Zylberberg \& Wake, 1990). However, a comparison of the dermal scale with the elasmoid scale of modern teleosts and aquatic sarcopterygians (coelacanths and lungfish) indicates a strong structural correspondence between the two elements. It is proposed that dermal scales are derived from a latent reactivation of the odontogenic capacity of trunk neural crest cells without a contribution from the osteogenic population. Whether the osteogenic cell population is lost or present but quiescent is unclear. Future studies documenting the development of dermal scales are necessary to test this hypothesis.

We can only speculate about the origin of the lamina calcarea and dermolita. Comparable to other hypermineralized tissues such as ganoine, hyaloine and the unnamed capping layer of some osteoderms, the lamina calcarea is 


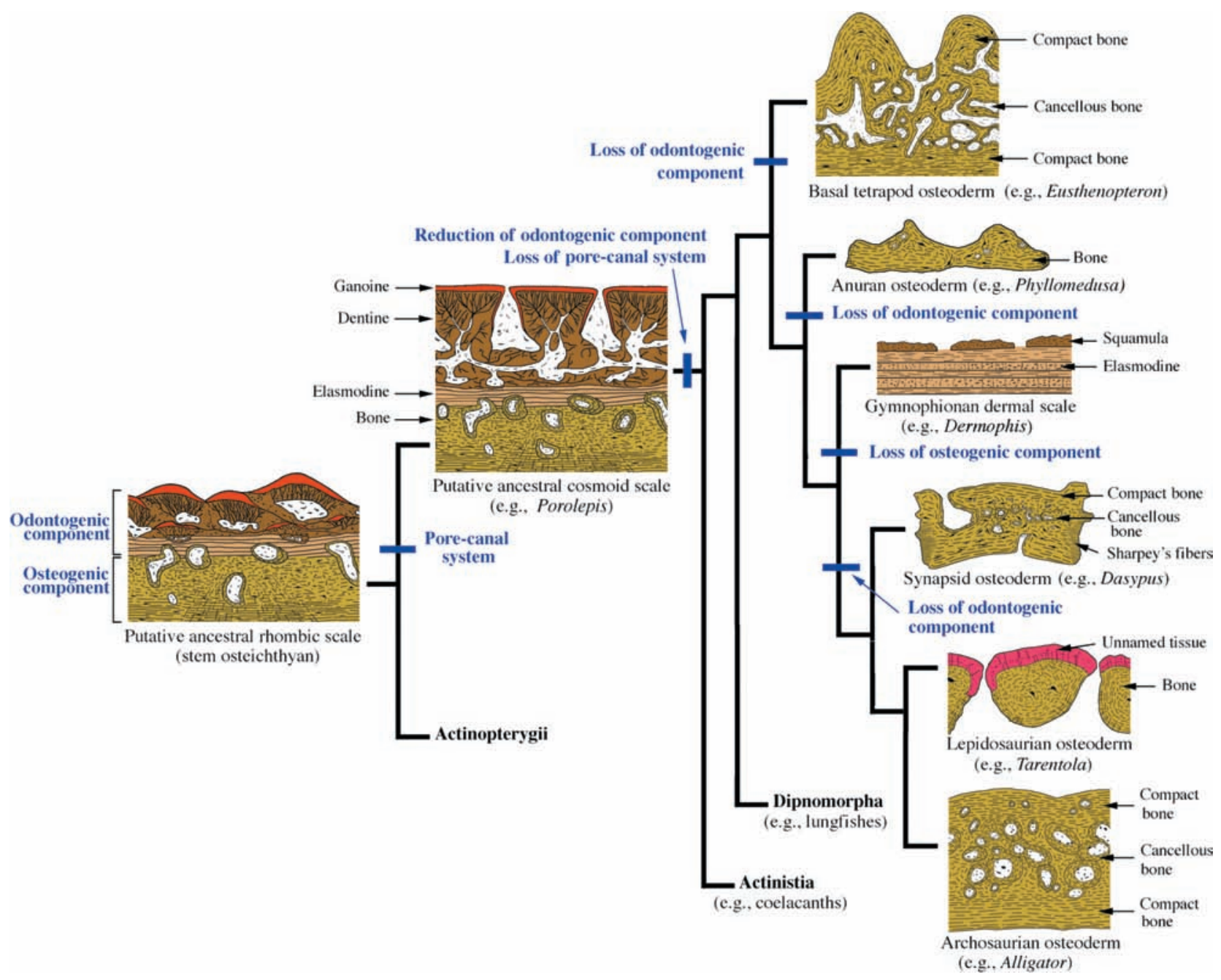

Fig. 10 A revised scenario depicting the evolution of the integumentary skeleton in tetrapods. The plesiomorphic integumentary skeletal element of osteichthyans is the rhombic scale. Following the work of Sire et al. (2009, this volume), we hypothesize that this ancestral scale is comparable to modern polypteroid-type ganoid scales with a stratified sequence of tissues derived from two separate populations of scleroblasts. Odontogenic cells give rise to layers of ganoine, dentine and elasmodine (a tissue as of yet unidentified in early fossil forms but predicted to exist). Osteogenic cells give rise to the bony basal plate. Among basal sarcopterygians, the superficial ganoine and dentine are penetrated by a ramifying pore-canal system. For most tetrapods, the pore-canal system and odontogenic tissue are lost (or no longer expressed), resulting in a bone-rich integumentary element known as an osteoderm. In gymnophionans, the odontogenic potential is retained (or reexpressed) while the osteogenic tissues are lost (or no longer expressed). In some lepidosaurs the osteoderm is capped by an unnamed tissue that is highly mineralized and collagen- and cell-poor. Although outwardly similar to ganoine, it is hypothesized that this tissue is an osteogenic derivative resulting from an inductive interaction with the overlying epidermis. See text for details. Schematic illustrations depicting longitudinal sections. Bone-rich tissue yellow, dentine brown, elasmodine beige, ganoine and hypermineralized tissues red. Not to scale.

a calcified tissue that lacks collagen and intrinsic cells. It is possible that the lamina calcarea is derived from an odontogenic cell population, albeit one that fails to form a discrete condensation. Reportedly, fibroblast-like cells contribute to the deposition of this tissue, possibly representing a poorly defined, migratory odontogenic population. Alternatively, the lamina calcarea may represent the competence of the overlying epithelium to deposit epithelial matrix products. Regrettably, this tissue remains largely enigmatic.

\section{Acknowledgements}

We would like to thank the many colleagues who provided us with materials and specimens for use in this study: Dr. J. Bogart and M. T. Rush (University of Guelph, Canada), Dr. J. Botha-Brink (University of the Free State, Bloemfontein, Republic of South Africa), Dr. D. Evans and K. Seymour (Royal Ontario Museum, Toronto, Canada), M. Burns (University of Alberta, Canada), Dr. A. P. Russell and W. Fitch (University of Calgary, Canada), Dr. M. Ryan and L. Russell (Cleveland Museum of Natural History, USA), and Dr. M. Wake (University of California at Berkeley, USA). 
Additional thanks to Dr. S. Modesto (Cape Breton University, Canada) for information about various fossil taxa, H. Maddin and W. Lei (University of Calgary, Canada) for assistance with the micro-computed tomography, and $\mathrm{H}$. Coates and W. Halina (University of Guelph, Canada) for histological preparations. We thank two anonymous reviewers for their valuable comments and careful critique of this manuscript.

\section{References}

Ahlberg PE (1991) A re-examination of sarcopterygian interrelationships, with special reference to the Porolepiformes. Zool J Linn Soc 103, 241-287.

Alexander RMN, Fariña R, Vizcaíno SF (1999) Tail blow energy and carapace fractures in a large glyptodont (Mammalia, Xenarthra). Zool J Linn Soc 126, 41-46.

Anderson JS (2007) Incorporating ontogeny into the matrix: a phylogenetic evaluation of developmental evidence for the origin of modern amphibians. In Major Transitions in Vertebrate Evolution (eds Anderson JS, Sues H-D), pp. 182-227. Bloomington, IN: Indiana University Press.

Anderson JS, Reisz RR, Scott D, Frobisch NB, Sumida SS (2008) A stem batrachian from the Early Permian of Texas and the origin of frogs and salamanders. Nature 453, 515-518.

Barrett PM, Clarck J, Brinkman DB, Chapman SD, Ensom PC (2002) Morphology, histology and identification of the 'granicones' from the Purbeck Limestone Formation (Lower Cretaceous: Berriasian) of Dorset, southern England. Cretac Res 23, 279-295.

Bauer AM, Russell AP (1989) Supraorbital ossifications in geckos (Reptilia: Gekkonidae). Can J Zool 67, 678-684.

Bever GS, Bell CJ, Maisano JA (2005) The ossified braincase and cephalic osteoderms of Shinisaurus crocodilurus (Squamata, Shinisauridae). Palaeontol Electron 8, 1-36.

Botha-Brink J, Modesto SP (2007) A mixed-age classed 'pelycosaur' aggregation from South Africa: earliest evidence of parental care in amniotes? Proc $R$ Soc Lond Ser B 274, 2829-2834.

Camp CL (1923) Classification of the lizards. Bull Am Mus Nat Hist 48, 289-482.

Castanet J, Francillon-Vieillot H, de Ricqles A, Zylberberg L (2003) The skeletal histology of the Amphibia. In Amphibian Biology, Vol. 5: Osteology (eds Heatwole H, Davies M), pp. 1598-1683. Chipping Norton, NSW: Surrey Beatty \& Sons.

Cebra-Thomas J, Betters E, Yin M, Plafkin C, McDow K, Gilbert SF (2007) Evidence that a late-emerging population of trunk neural crest cells forms the plastron bones in the turtle Trachemys scripta. Evol Dev 9, 267-277.

Cisneros JC (2008). Phylogenetic relationships of procolophonid parareptiles with remarks on their geological record. J Syst Palaeontol 6, 345-366.

Clark K, Bender G, Murray BP, et al. (2001) Evidence for the neural crest origin of turtle plastron bones. Genesis 31, 111-117.

Cloutier R (1991) Patterns, trends, and rates of evolution within the Actinistia. Environ Biol Fish 32, 23-58.

Cole AC, Hall BK (2004) The nature and significance of invertebrate cartilages revisited: distribution and histology of cartilage and cartilage-like tissues within Metazoa. Zoology 107, 261273.

Conrad JL (2008) Phylogeny and systematics of Squamata (Reptilia) based on morphology. Bull Am Mus Nat Hist 310, 1-182.

Conrad JL, Norell MA (2007) A complete Late Cretaceous iguanian (Squamata, Reptilia) from the Gobi and identification of a new iguanian clade. Am Mus Novit 3584, 1-47.
Coombs W Jr (1972) The bony eyelid of Euoplocephalus (Reptilia, Ornithischia). J Paleontol 46, 637-650.

Coombs W Jr (1995) Ankylosaurian tail clubs of middle Campanian to early Maastrichtian age from western North America, with description of a tiny club from Alberta and discussion of tail orientation and tail club function. Can J Earth Sci 32, 902-912.

Cooper ZK (1930) A histological study of the integument of the armadillo, Tatusia novemcincta. Am J Anat 45, 1-37.

Cope ED (1868) An examination of the Reptilia and Batrachia by the Orton Expedition to Equador and the Upper Amazon, with notes on other species. Proc Acad Nat Sci Philadelphia 20, 96140.

Couly G, Coltey PM, Le Douarin NM (1993) The triple origin of the skull in higher vertebrates: a study of quail-chick chimeras. Development 117, 409-429.

Creuzet S, Couly G, Le Douarin N (2005) Patterning the neural crest derivative during development of the vertebrate head: insights from avian studies. J Anat 207, 447-459.

Daeschler ED, Shubin NH, Jenkins FA Jr (2006) A Devonian tetrapodlike fish and the evolution of the tetrapod body plan. Nature 440, 757-763.

de Buffrénil V, Farlow J, de Ricqlès A (1986) Growth and function of Stegosaurus plates: evidence from bone histology. Paleobiology 12, 459-473.

de Queiroz K (1987) Phylogenetic systematics of iguanian lizards: a comparative osteological study. Univ Calif Publ Zool 118, 1-203.

de Ricqlès A, Meunier FJ, Castanet J, Francillon-Vieillot H (1991) Comparative microstructure of bone. In Bone, Vol. 3. Bone Matrix and Bone Specific Products (ed. Hall BK), pp. 1-78. Boca Raton, FL: CRC Press.

de Ricqlès A, Pereda Suberbiola X, Gasparini Z, Olivero E (2001) Histology of dermal ossifications in an ankylosaurian dinosaur from the Late Cretaceous of Antarctica. In International Symposium on Mesozoic Terrestrial Ecosystems (ed. Leanza HA), pp. 171174. Buenos Aires: Asociación Paleontológica Argentina.

DeMar RE (1966) The phylogenetic and functional implications of the armor of the Dissorophidae. Fieldiana: Geol 16, 55-88.

Deraniyagala MA (1939) The Tetrapod Reptiles of Ceylon, Vol. I. Testudinates and Crocodilians. Colombo Ceylon: Colombo Museum of Natural History.

Dhouailly D, Olivera-Martinez I, Fliniaux I, Missier S, Viallet JP, Thelu J (2004) Skin field formation: morphogenetic events. Int J Dev Biol 48, 85-91.

Dias EV, Richter M (2002) On the squamation of Australerpeton cosgriffi Barberena, a temnospondyl amphibian from the Upper Permian of Brasil. An Acad Bras Ciênc 74, 477-490.

Dilkes D, Brown LE (2007) Biomechanics of the vertebrae and associated osteoderms of the Early Permian amphibian Cacops aspidephorus. J Zool 271, 396-407.

Dodson P, Krause DW, Forster CA, Sampson SD, Ravoavy F (1998) Titanosaurid (Sauropoda) osteoderms from the Late Cretaceous of Madagascar. J Vertebr Paleontol 18, 562-568.

Dong Z, Peng G, Huang D (1989) [The discovery of the bony tail club of sauropods]. Vertebr Palasiat 27, 219-224.

Donoghue P, Sansom I, Downs J (2006) Early evolution of vertebrate skeletal tissues and cellular interactions, and the canalization of skeletal development. J Exp Zool Mol Dev Evol 306B, 278-294.

Elkan E (1976) Ground substance: an anuran defense against dessication. In Physiology of the Amphibia (ed. Lofts B), pp. 101110. New York: Academic Press.

Enlow DH, Brown SO (1957) A comparative histological study of fossil and recent bone tissues. Part II. Tex J Sci 9, 186-214. 
Erickson GM, de Ricqles A, de Buffrénil V, Molnar RE, Bayless MK (2003) Vermiform bones and the evolution of gigantism in Megalania - how a reptilian fox became a lion. J Vertebr Paleontol 23, 966-970.

Estes R, de Queiroz K, Gauthier JA (1988) Phylogenetic relationships within Squamata. In Phylogenetic Relationships of the Lizard Families (eds Estes R, Pregill G), pp. 119-291. Stanford, CA: Stanford University Press.

Ewer RF (1965) The anatomy of the thecodont reptile Euparkeria capensis Broom. Philos Trans $R$ Soc London 248, 379-435.

Fabrezi M (2006) Morphological evolution of Ceratophryinae (Anura, Neobatrachia). J Zool Syst Evol Res 44, 153-166.

Francillon-Vieillot H, de Buffrénil V, Castanet J, et al. (1990) Microstructure and mineralization of vertebrate skeletal tissues. In Skeletal Biomineralization; Patterns, Processes and Evolutionary Trends, Vol. 1 (ed. Carter JG), pp. 471-548. New York: Van Nostrand Reinhold.

Frey E (1988) The carrying system of crocodilians: a biomechanical and phylogenetic analysis. Stuttg Beitrr Naturk Ser A 426, 1-60.

Gadow H (1901) Cambridge Natural History, Vol VIII: Amphibia and Reptiles. New York: Hafner Publishing Company.

Gaffney ES (1990) The comparative osteology of the Triassic turtle Proganochelys. Bull Am Mus Nat Hist 194, 1-263.

Gaffney ES (1996) The postcranial morphology of Meiolania platyceps and a review of the Meiolaniidae. Bull Am Mus Nat Hist 229, 1-166.

Gans C, Northcutt R (1983) Neural crest and the origin of vertebrates: A new head. Science 220, 268-273.

Gao K, Norell MA (2000) Taxonomic composition and systematics of late Cretaceous lizard assemblages from Ukhaa Tolgod and adjacent localities, Mongolian Gobi Desert. Bull Am Mus Nat Hist 249, 1-118.

Gaudin TJ, Wible JR (2006) The phylogeny of living and extinct armadillos (Mammalia, Xenarthra, Cingulata): a craniodental analysis. In Amniote Paleobiology: Perspectives on the Evolution of Mammals, Birds and Reptiles (eds Carrano MT, Gaudin TJ, Blob RW, Wible JR), pp. 153-198. Chicago: University of Chicago Press.

Gilbert SF, Loredo GA, Brukman A, Burke AC (2001) Morphogenesis of the turtle shell: the development of a novel structure in tetrapod evolution. Evol Dev 3, 47-58.

Gilbert SF, Bender G, Betters E, Yin M, Cebra-Thomas J (2007) The contribution of neural crest cells to the nuchal bone and plastron of the turtle shell. Integr Comp Biol 47, 401-408.

Goodrich ES (1907) On the scales of fish, living and extinct, and their importance in classification. Proc Zool Soc London 77, 751-774.

Grant C (1944) Scale structure in Jamaican lizards of the genus Celestus. Copeia 1944, 109-111.

Graveson AC, Smith MM, Hall BK (1987) Neural crest potential for tooth development in a urodele amphibian: Developmental and evolutionary significance. Dev Biol 188, 34-42.

Greer AE (1989) The Biology and Evolution of Australian Lizards. Chipping Norton, NSW: Surrey Beatty \& Sons Pty Limited.

Hall BK (1999) The Neural Crest in Development and Evolution. New York: Springer-Verlag.

Hall BK, Hörstadius S (1988) The Neural Crest. Oxford: Oxford University Press.

Hay OP (1898) On Protostega, the systematic position of Dermochelys, and the morphogeny of the chelonian carapace and plastron. Am Nat 32, 929-948.

Haynes G (1991) Mammoths, Mastodonts, and Elephants - Biology, Behavior, and the Fossil Record. New York: Cambridge University Press.
Hill RV (2005) Integrative morphological data sets for phylogenetic analysis of Amniota: the importance of integumentary characters and increased taxonomic sampling. Syst Bio/ 54, 530-547.

Hill RV (2006) Comparative anatomy and histology of xenarthran osteoderms. J Morphol 2667, 1441-1460.

Hill RV, Lucas SG (2006) New data on the anatomy and relationship of the Paleocene crocodylian Akanthosuchus langstoni. Acta Palaeontol Pol 51, 455-464.

Hoffstetter R (1962) Observations sur les ostéodermes et la classification des anguidés actuels et fossiles (Reptilia, Sauria). Bull Mus Natl Hist Nat 34, 149-157.

Hutton J (1986) Age determination of living Nile crocodiles from the cortical stratification of bone. Copeia 1986, 332-341.

Huxley TH (1860) On the dermal armour of Jacare and Caiman, with some notes on the specific and generic characters of recent Crocodilia. J Proc Linn Soc Lon 4, 1-28.

Huysseune A (2000) Skeletal system. In Microscopic Functional Anatomy (ed. Ostrander GK), pp. 307-317. San Diego: Academic Press.

Jacobs LL, Winkler DA, Murry PA, Maurice JM (1994) A nodosaurid scuteling from the Texas shore of the Western Interior Seaway. In Dinosaur Eggs and Babies (eds Carpenter K, Hirsch KF, Horner JR), pp. 337-346. New York: Cambridge University Press.

Janvier P (1996) Early Vertebrates. Oxford: Clarendon Press.

Janvier $\mathbf{P}$ (2007) Living primitive fishes and fishes from deep time. In Primitive Fishes, Vol. 26. Fish Physiology (eds Mckenzie DJ, Farrell AP, Brauner CJ), pp. 1-51. New York: Elsevier.

Jarvik E (1980) Basic Structure and Evolution of Vertebrates, Vol. 1. New York: Academic Press.

Joyce W, Lucas SG, Scheyer TM, Heckert AB, Hunt AP (2008). A thin-shelled reptile from the Late Triassic of North America and the origin of the turtle shell. Proc $R$ Soc B Lond Biol Sci doi:10.1098/rspb.2008.1196.

Katchburian E, Antoniazzi MM, Jared C, Faria FP, Souza Santos H, Freymuller E (2001) Mineralized dermal layer of the Brazilian tree-frog Corythomantis greeningi. J Morpho/ 248, 56-63.

Krause DW, Evans SE, Gao K (2003) First definitive record of Mesozoic lizards from Madagascar. J Vertebr Paleonto/ 23, 842856.

Krejsa R (1979) The comparative anatomy of the integumental skeleton. Hyman's Comp Vertebr Anat 3, 112-191.

Krmpotic CM, Ciancio MR, Barbeito C, Mario RC, Carlini AA (2008) Osteoderm morphology in recent and fossil euphractine xenarthrans. Acta Zool (Stockh) doi: 10/1111/j.1463-6395.2008.00359.x.

Le Lièvre CS, Le Douarin NM (1975) Mesenchymal derivatives of the neural crest: analysis of chimaeric quail and chick embryos. $J$ Embryol Exp Morphol 34, 125-154.

Lee MSY (1997) Pareiasaur phylogeny and the origin of turtles. Zool J Linn Soc 120, 197-280.

Levrat-Calviac V (1986-1987) Étude comparée des ostéodermes de Tarentola mauritanica et de $T$. neglecta (Gekkonidae, Squamata). Arch Anat Microsc Morphol Exp 75, 29-43.

Levrat-Calviac V, Zylberberg L (1986) The structure of the osteoderms in the Gekko: Tarentola mauritanica. Am J Anat 176, 437-446.

Levrat-Calviac V, Castanet J, Zylberberg L (1986) The structure of the osteoderms in two lizards: Tarentola mauritanica and Anguis fragilis. In Studies in Herpetology: Proceedings of the European Herpetological Meeting (ed. Rocek Z), pp. 341-344. Prague: Charles University.

Li C, Wu X-C, Cheng Y, Sato T, Wang L (2006) An unusual archosaurian from the marine Triassic of China. Naturwissenschaften 93, 200-206. 
Li C, Wu X-C, Rieppel O, Wang L-T, Zhao L-J (2008) An ancestral turtle from the Late Triassic of southwestern China. Nature 456, 497-501.

Long JA, Young GC, Holland T, Senden TJ, Fitzgerald EMG (2006) An exceptional Devonian fish from Australia sheds light on tetrapod origins. Nature 444, 199-202.

Loveridge A (1947) Revision of the African lizards of the family Gekkonidae. Bull Mus Comp Zool 98, 1-469.

Lumsden A (1987) The neural crest contribution to tooth development in the mammalian embryo. In Developmental and Evolutionary Aspects of the Neural Crest (ed. Maderson PFA), pp. 261-300. New York: John Wiley \& Sons.

Lumsden A (1988) Spatial organization of the epithelium and the role of neural crest cells in the initiation of the mammalian tooth germ. Development 102 (Suppl), 155-169.

Lynch J (1982) Relationships of the frogs of the genus Ceratophrys (Leptodactylidae) and their bearing on hypotheses of Pleistocene forest refugia in South America and punctuated equilibria. Syst Zool 31, 166-179.

Main RP, de Ricqlès A, Horner JR, Padian K (2005) The evolution and function of thyreophoran dinosaur scutes: implications for plate function in stegosaurs. Paleobiology 31, 291-314.

Maisano JA, Bell CJ, Gauthier JA, Rowe T (2002) The osteoderms and palpebral in Lanthanotus borneensis (Squamata: Anguimorpha). J Herpetol 36, 678-682.

Martill DM, Batten DJ, Loydell DK (2000) A new specimen of the thyreophoran dinosaur cf. Scelidosaurus with soft tissue preservation. Palaeontology 43, 549-559.

Martz JW, Small BJ (2006) Tecovasuchus chatterjeei, a new aetosaur (Archosauria: Stagonolepididae) from the Tecovas Formation (Carnian, Upper Triassic) of Texas. J Vertebr Paleontol 26, 308-320.

Maryañska T (1977) Ankylosauridae (Dinosauria) from Mongolia. Acta Palaeontol Pol 37, 85-151.

Mauger A (1972a) The role of somitic mesoderm in the development of dorsal plumage in chick embryos. I. Origin, regulative capacity and determination of the plumage-forming mesoderm. J Embryol Exp Morphol 28, 313-341.

Mauger A (1972b) The role of somitic mesoderm in the development of dorsal plumage in chick embryos. II. Regionalization of the plumage-forming mesoderm. J Embryol Exp Morphol 28, 343-366.

McDowell SM, Jr, Bogert CM (1954) The systematic position of Lanthanotus and the affinities of the anguinomorphan lizards. Bull Am Mus Nat Hist 105, 1-142.

McGowan G, Evans SE (1995). Albanerpetontid amphibians from the Cretaceous of Spain. Nature 373, 143-145.

Meinke DH (1984) A review of cosmine: its structure, development, and relationship to other forms of the dermal skeleton of osteichthyans. J Vertebr Paleontol 4, 457-470.

Meylan PA (1987) The phylogenetic relationships of soft-shelled turtles (Family Trionychidae). Bull Am Mus Nat Hist 186, 1101.

Miyake T, Vaglia JL, Taylor LH, Hall BK (1999) Development of dermal denticles in skates (Chondrichthyes, Batoidea): patterning and cellular differentiation. J Morpho/ 241, 61-81.

Moss ML (1969) Comparative histology of dermal sclerifications in reptiles. Acta Anat 73, 510-533.

Moss M (1972) The vertebrate dermis and the integumental skeleton. Am Zool 12, 27-34.

Moustakas J (2008) Development of the carapacial ridge: implications for the evolution of genetic networks in turtle shell development. Evol Dev 10, 29-36.
Muzii EO (1968) Dermal calcifications of anurans: their composition and ultrastructure. In Les Tissus Calcifiés, Fifth European Symposium, pp. 377-382. Sedes: Société d'édition d'enseignement supèrieur.

Nagashima H, Uchida K, Yamamoto K, Kuraku S, Usuda R, Kuratani S (2005) Turtle-chicken chimera: an experimental approach to understanding evolutionary innovation in the turtle. Dev Dyn 232, 149-161.

Naish D (2004) Placodonts. Geol Today 20, 153-158.

Nicholls E, Brinkman D, Wu X (1998) A new archosaur from the Upper Triassic Pardonet Formation of British Columbia. Can J Earth Sci 35, 1134-1142.

Olson EC (1979). Aspects of the biology of Trimerorhachis (Amphibia: Temnospondyli). J Paleontol 53, 1-17.

Ørvig T (1957) Remarks on the vertebrate fauna of the Lower Upper Devonian of Escuminac Bay, P.Q., Canada, with special reference to the porolepiform crossopterygians. Ark Zool 10, 367-426.

Otto H (1909) Die Beschuppung der Brevilinguier und Ascalaboten. Jena Z Naturwiss 44, 193-252.

Owen R (1849) On the development and homologies of the carapace and plastron of the chelonian reptiles. Philos Trans $R$ Soc Lond 139, 151-171.

Parker HW (1942) The lizards of British Somaliland. Bull Mus Comp Zool 91, 1-101.

Read R (1986) Osteoderms in the Lacertilia: an investigation into the structure and phylogenetic implications of dermal bone found under the skin of lizards. PhD Thesis, Department of Biological Sciences, 142 p. Fullerton, CA: California State University.

Reisz RR, Modesto SP (2007) Heleosaurus scholtzi from the Permian of South Africa: a varanopid synapsid, not a diapsid reptile. J Vertebr Paleontol 27, 734-739.

Reisz R, Dilkes DW, Berman DS (1998) Anatomy and relationships of Elliotsmithia longiceps Broom, a small synapsid (Eupelycosauria: Varanopseidae) from the late Permian of South Africa. $J$ Vertebr Paleontol 18, 602-611.

Reynoso V-H (1997) A 'beaded' sphenodontian (Diapsida: Lepidosauria) from the Early Cretaceous of Central Mexico. J Vertebr Paleontol 17, 52-59.

Rieppel $O$ (2001) Turtles as hopeful monsters. BioEssays 23, 987991.

Rieppel O (2002) The dermal armor of the cyamodontoid placodonts (Reptilia, Sauropterygia): morphology and systematic value. Fieldiana: Geol New Ser 46, 1-41.

Rieppel O, Reisz R (1999) The origin and early evolution of turtles. Annu Rev Ecol Syst 30, 1-22.

Romer AS (1956) Osteology of the Reptiles. Chicago: University of Chicago Press.

Ross FD, Mayer GC (1983) On the dorsal armor of the Crocodilia. In Advances in Herpetology and Evolutionary Biology (ed. Rhodin AGJ), pp. 305-331. Cambridge, MA: Museum of Comparative Zoology.

Ruibal R, Shoemaker V (1984) Osteoderms in anurans. J Herpetol 18, 313-328.

Salisbury SW, Frey E (2000). A biomechanical transformation model for the evolution of semi-spheroidal articulations between adjoining vertebral bodies in crocodilians. In Crocodilian Biology and Evolution (ed. Grigg GC, Seebacher F, Franklin CE), pp. 85134. Chipping Norton, NSW: Surrey Beatty \& Sons.

Sampson HW, Cannon MJ, Davis RW (1987) The calcified amorphous layer of the skin of Bufo marinus (Amphibia: Anura). $J$ Zool 213, 63-69. 
Scheyer TM (2007) Skeletal histology of the dermal armor of Placodontia: the occurrence of 'postcranial fibro-cartilaginous bone' and its developmental implications. J Anat 211, 737753.

Scheyer TM, Sanchez-Villagra M (2007) Carapace bone histology in the giant pleurodiran turtle Stupendemys geographicus: Phylogeny and function. Acta Palaeontol Pol 52, 137-154.

Scheyer TM, Sander PM (2004) Histology of ankylosaur osteoderms: implications for systematics and function. J Vertebr Paleonto/ 24, 874-893.

Scheyer TM, Sander P (2007) Shell bone histology indicates terrestrial palaeoecology of basal turtles. Proc $R$ Soc B Lond Biol Sci 274, 1885-1893.

Scheyer TM, Sander PM, Joyce W, Böhme W, Witzel U (2007) A plywood structure in the shell of fossil and living soft-shelled turtles (Trionychidae) and its evolutionary implications. Org Divers Evol 7, 136-144.

Scheyer TM, Brüllmann B, Sánchez-Villagra MR (2008). The ontogeny of the shell in side-necked turtles, with emphasis on the homologies of costal and neural bones. J Morphol 269, 1008-1021.

Schmidt WJ (1912) Studien am Integument der Reptilien. I. Die Haut der Geckoniden. Z Wiss Zool 101, 140-252.

Schmidt WJ (1914) Studien am Integument der Reptilien. VI. Uber die Knochenschuppen der Crocodile. Zool Jahrb Abt Anat Ontog Tiere 38, 643-666.

Schoch RR (2003) Early larval ontogeny of the Permo-Carboniferous temnospondyl Sclerocephalus. Palaeontology 46, 1055-1072.

Schwinger G, Zanger K, Greven H (2001) Structural and mechanical aspects of the skin of Bufo marinus (Anura, Amphibia). Tissue Cell 33, 541-547.

Seidel MR (1979) The osteoderms of the American alligator and their functional significance. Herpetologica 35, 375-380.

Shafritz AB, Shore EM, Gannon FH, et al. (1996) Overexpression of an osteogenic morphogen in fibrodysplasia ossificans progressiva. New Engl J Med 335, 555-561.

Sibtain SM (1938) Studies of the caudal autotomy and regeneration of Mabuya dissimilis Hallowell. Proc Indian Acad Sci Sec B 8, 63-78.

Sire J-Y (1990) From ganoid to elasmoid scales in the actinopterygian fishes. Nether $J$ Zool 40, 75-92.

Sire J-Y (1993) Development and fine structure of the bony scutes in Corydoras arcuatus (Siluriformes, Callichthyidae). J Morphol 215, 225-244.

Sire J-Y, Huysseune A (2003) Formation of dermal skeletal and dental tissues in fish: a comparative and evolutionary approach. Biol Rev 78, 219-249.

Sire J-Y, Géraudie J, Meunier F, Zylberberg L (1987) On the origin of ganoine: histological and ultrastructural data on the experimental regeneration of the scales of Calamoichthys calabaricus (Osteichthyes, Brachyopterygii, Polypteridae). Am J Anat 180, 391-402.

Sire J-Y, Donoghue PC, Vickaryous MK (2009) Origin and evolution of the integumentary skeleton in non-tetrapod vertebrates. J Anat 214, 409-440.

Smith MM, Hall BK (1990) Developmental and evolutionary origins of vertebrate skeletogenic and odontogenic tissues. Biol Rev 65, 277-374.

Smith MM, Hall BK (1993) A developmental model for evolution of the vertebrate exoskeleton and teeth: role of cranial and trunk neural crest. Evol Bio/ 27, 387-448.

Smith MM, Hickman A, Amanze D, Lumsden A, Thorogood P (1994) Trunk neural crest origin of caudal fin mesenchyme in the zebrafish Brachydanio rerio. Proc $R$ Soc B: Biol Sci 256, 137 145.

Strahm MH, Schwartz A (1977) Osteoderms in the anguid lizard subfamily Diploglossinae and their taxonomic importance. Biotropica 9, 58-72.

Taylor RE, Taylor HC, Barker SB (1966) Chemical and morphological studies on inorganic phosphate deposits in Rana catesbeiana skin. J Exp Zool 161, 271-286.

Toledo RC, Jared C (1993) The calcified dermal layer in anurans. Comp Biochem Physiol Part A 104, 443-448.

Tosney KW (2004) Long-distance cue from emerging dermis stimulates neural crest melanoblast migration. Dev Dyn 229, 99-108.

Trueb L (1973) Bones, frogs, and evolution. In Evolutionary Biology of the Anurans. Contemporary Research on Major Problems (ed. Vial L), pp. 65-132. Columbia, MO: University of Missouri Press.

Tucker A (1997) Validation of skeletochronology to determine age of freshwater crocodiles (Crocodylus johnstoni). Mar Freshw Res 48, 343-351.

Verhaagh M, Greven H (1982) Localization of calcium in fibrocytes associated with the 'substantia amorpha' in the skin of the toad, Bufo bufo (L.) (Amphibia, Anura). Acta Histochem 70, 139149.

Vickaryous MK (2006) New information on the cranial anatomy of Edmontonia rugosidens, a Late Cretaceous nodosaurid dinosaur from Dinosaur Provincial Park, Alberta. J Vertebr Paleontol 26, 1011-1013.

Vickaryous MK, Hall BK (2006) Osteoderm morphology and development in the nine-banded armadillo, Dasypus novemcinctus (Mammalia, Xenarthra, Cingulata). J Morphol 267, 1273-1283.

Vickaryous MK, Hall BK (2008) Development of the dermal skeleton in Alligator mississippiensis (Archosauria, Crocodylia) with comments on the homology of osteoderms. J Morpho/ 269, 398422.

Vickaryous MK, Russell AP (2003) A redescription of the skull of Euoplocephalus tutus (Archosauria: Ornithischia): A foundation for comparative and systematic studies of ankylosaurian dinosaurs. Zool J Linn Soc 137, 157-186.

Vickaryous MK, Russell AP, Currie PJ (2001) The cranial ornamentation of ankylosaurs (Ornithischia: Thyreophora): reappraisal of developmental hypotheses. In The Armored Dinosaurs (ed. Carpenter K), pp. 318-340. Bloomington, IN: Indiana University Press.

Vickaryous MK, Maryañska T, Weishampel DB (2004) Ankylosauria. In The Dinosauria, 2nd edn (eds Weishampel DB, Dodson P, Olsmolska H), pp. 363-392. Berkeley: University of California Press.

Wilson CW (1914) Development and histology of the integument of the nine-banded armadillo (Tatusia novemcincta). Bull Univ Tex Sci Ser 36, 1-18.

Witzmann F (2007) The evolution of the scalation pattern in temnospondyl amphibians. Zool J Linn Soc 150, 815-834.

Yu X-B (1998) A new porolepiform-like fish Psarolepis romeri gen. et sp. nov. (Sarcopterygii, Osteichthyes) from the Lower Devonian of Yunnan, China. J Vertebr Paleontol 18, 261-274.

Zangerl R (1939) The homology of the shell elements in turtles. J Morphol 65, 383-409.

Zangerl R (1969) The turtle shell. In Biology of the Reptilia, Morphology A, vol. 1 (eds Bellairs ADA, Parsons TS), pp. 311339. New York: Academic Press.

Zhu M, Ahlberg P (2004) The origin of the internal nostril of tetrapods. Nature $432,94-97$. 
Zhu M, Yu X (2002) A primitive fish close to the common ancestor of tetrapods and lungfish. Nature 418, 767-770.

Zhu M, Yu X, Janvier P (1999) A primitive fossil fish sheds light on the origin of bony fishes. Nature 397, 607-610.

Zhu M, Yu X, Ahlberg PE (2001) A primitive sarcopterygian fish with an eyestalk. Nature 410, 81-84.

Zhu M, Yu X, Wang W, Zhao W, Jia L (2006) A primitive fish provides key characters bearing on deep osteichthyan phylogeny. Nature 441, 77-80.

Zylberberg L, Castanet J (1985) New data on the structure and growth of the osteoderms in the reptile Anguis fragilis L. (Anguidae, Squamata). J Morphol 186, 327-342.
Zylberberg L, Wake MH (1990) Structure of the scales of Dermophis and Microcaecilia (Amphibia: Gymnophiona) and a comparison to dermal ossifications of other vertebrates. J Morphol 206, 25-43.

Zylberberg L, Castanet J, de Ricqles A (1980) Structure of the dermal scales in Gymnophiona (Amphibia). J Morphol 165, 4154.

Zylberberg L, Geraudie J, Meunier F, Sire J-Y (1992) Biomineralization in the integumental skeleton of the living lower vertebrates. In Bone, Vol. 4: Bone Metabolism and Mineralization (ed. Hall BK), pp. 171-224. Boca Raton, FL: CRC Press. 